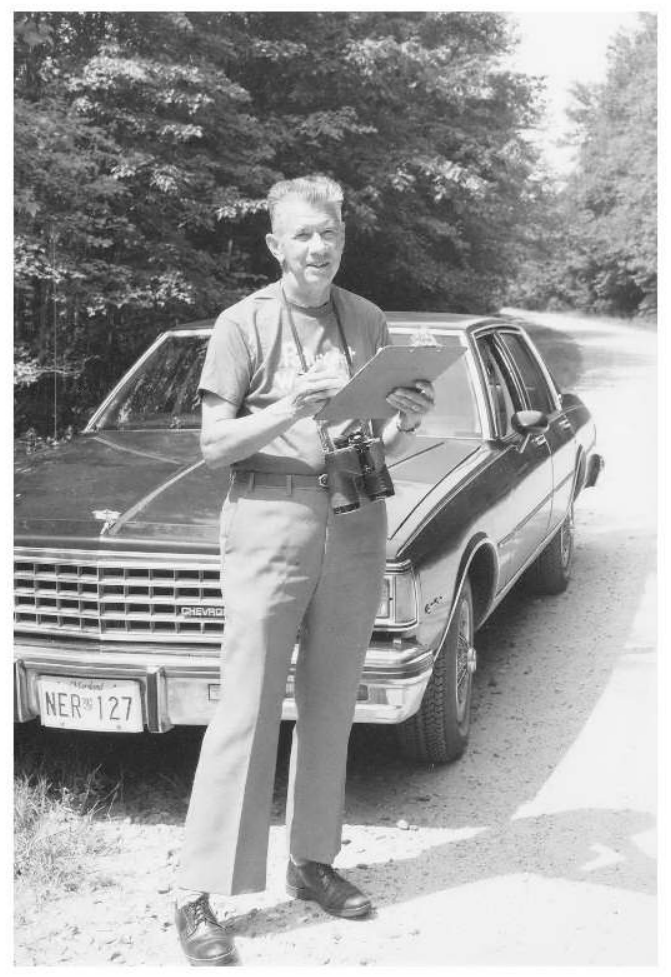

Frontispiece. Chandler S. Robbins counting birds at a North American Breeding Bird Survey stop, ca. 1985. Photograph by Barbara A. Dowell. 


\title{
The North American Breeding Bird Survey 1966-2011: Summary Analysis and Species Accounts
}

John R. Sauer*, William A. Link, Jane E. Fallon, Keith L. Pardieck, David J. Ziolkowski Jr. United States Geological Survey, Patuxent Wildlife Research Center, 12100 Beech Forest Road, Laurel, Maryland 20770

\begin{abstract}
The North American Breeding Bird Survey is a roadside, count-based survey conducted by volunteer observers. Begun in 1966, it now is a primary source of information on spatial and temporal patterns of population change for North American birds. We analyze population change for states, provinces, Bird Conservation Regions, and the entire survey within the contiguous United States and southern Canada for 426 species using a hierarchical log-linear model that controls for observer effects in counting. We also map relative abundance and population change for each species using a spatial smoothing of data at the scale of survey routes. We present results in accounts that describe major breeding habitats, migratory status, conservation status, and population trends for each species at several geographic scales. We also present composite results for groups of species categorized by habitats and migratory status. The survey varies greatly among species in percentage of species' range covered and precision of results, but consistent patterns of decline occur among eastern forest, grassland, and aridland obligate birds while generalist bird species are increasing.
\end{abstract}

Keywords: hierarchical models; population survey; species groups

Received: October 27, 2011; Accepted: July 12, 2013; Published Online Early: August 2013; Published: December 2013

Citation: Sauer JR, Link WA, Fallon JE, Pardieck KL, Ziolkowski DJ Jr. 2013. The North American Breeding Bird Survey 1966-2011: Summary Analysis and Species Accounts. North American Fauna 79: 1-32. doi:10.3996/nafa.79.0001

Copyright: All material appearing in North American Fauna is in the public domain and may be reproduced or copied without permission unless specifically noted with the copyright symbol @. Citation of the source, as given above, is requested.

The findings and conclusions in this article are those of the author(s) and do not necessarily represent the views of the U.S. Fish and Wildlife Service.

* Corresponding author: jrsauer@usgs.gov

Subject Editor: Colleen Handel, United States Geological Survey, Anchorage, Alaska

\section{Introduction}

The North American Breeding Bird Survey (BBS) is a unique collaborative effort to increase our understanding of North American bird populations. Started at a time when concern about bird populations was focused on effects of pesticides, the BBS now serves as the primary data source for estimating population changes of North American birds and for modeling the possible consequences of changes in land use, climate, and many other possible stressors on bird populations. Jointly coordinated by the United States Geological Survey, the Canadian Wildlife Service, and, since 2008, the Mexican National Commission for the Knowledge and Use of Biodiversity, the BBS incorporates the efforts of thousands of volunteer bird counters across the
United States, Canada, and Mexico. From their efforts, comprehensive summaries of population change have been calculated for $>400$ species of birds (Sauer et al. 2003). For most of these species, the BBS forms the only source of information on the dynamics of the populations. BBS observers must be able to identify birds by sound and sight, and the attention placed on competence of observers (at first informally, and more recently through online training programs) greatly increased the rigor of the information, paving the way for additional bird survey programs that rely on volunteer observers. Although it has limitations, no other survey comes close in combining public participation and scientific rigor to provide information for bird conservation and natural history. 
This summary of BBS results presents a synthesis of information on bird population change and distribution. We integrate habitat and migration status information, distribution maps depicting relative abundance, and current estimates and graphical illustrations of population change into accounts for 426 species of North American birds. The accounts provide a concise description of both the present efficiency of the survey, in terms of precision of estimate of population change, and the population status for each species as described by the survey. We also present analyses of multispecies groups to summarize patterns of population change for groups of conservation interest. By providing a survey-wide overview of species coverage by the BBS, this volume complements earlier comprehensive summaries of the BBS (Robbins et al. 1986; Sauer et al. 2003). Detailed regional information regarding population change for all species is available on the BBS Summary and Analysis website (Sauer et al. 2011).

\section{A Brief History of the North American BBS}

The North American BBS was developed in response to a need for better information about population change in songbirds in North America. Although legal requirements for management of harvested species led to the development of continent-scale surveys for waterfowl in the 1950s (Martin et al. 1979), no such surveys existed for nongame birds. However, with the publication of Rachel Carson's Silent Spring (Carson 1962) and the ensuing increased public awareness of threats to nongame bird populations, a need quickly became apparent. It was evident that the paucity of current information about populations of most bird species and the lack of a scheme by which to collect future data severely limited our ability to assess the consequences of pesticides and other stressors on these species.

Chandler S. Robbins, who was already a distinguished researcher in bird populations at the Patuxent Wildlife Research Center in Laurel, Maryland, was able to convince his superiors in the U.S. Fish and Wildlife Service of the need for a continent-scale monitoring program for nongame birds. Robbins realized that roadside-based survey methods that he and colleagues had previously used for monitoring mourning dove Zenaida macroura and American woodcock Scolopax minor could be modified to count many species simultaneously. $\mathrm{He}$ was already an influential member of the growing birdwatching community and knew that a competent observer workforce could be recruited for such an effort. Robbins experimented with alternative approaches to counting birds for several years before settling on the protocol that is still used today. $\mathrm{He}$ implemented a pilot effort in Maryland and Delaware in 1965 and then inaugurated the survey in the eastern United States in 1966. Canadian collaborators, particularly Anthony Erskine, implemented the survey in southeastern Canada in 1966 as well. Survey routes were established in the central United States in 1967, and by 1968 the sampling framework had grown to include the continental United States and much of southern Canada. Subsequently, additional survey routes have been established, including efforts to get better information from remote regions of the western United States and northern Canada. Alaska also has many BBS routes along the limited road system $(\sim 70$ routes sampled each year 1993 to present), but few samples prior to 1993. Consequently, Alaska data cannot be analyzed for time periods comparable to other regions. Alaska trends for recent years have been presented on the BBS Analysis and Summary Website (Sauer et al. 2011), and research is underway to assess the feasibility of developing a combined on- and off-road survey to provide a more comprehensive survey of the state (Colleen Handel, U.S. Geological Survey [USGS], personal communication). BBS-style surveys were conducted in Puerto Rico from 1997 to 2007, and an expansion of the survey into Mexico began in earnest with the establishment of routes in northern areas starting in 2008.

By 2010, there were 5,267 survey routes in the database and 3,140 of them were surveyed in 2010 . Coverage varies across North America (Figure 1). Using routes per degree block as a summary statistic (as calculated from degree blocks within the current BBS analysis area, see Maps of Relative Abundance) comparatively fewer routes occur in the western United States $\langle\bar{x}=2.73$ [95\% Confidence interval: $2.62,2.83], N=680$ west of the 100 th meridian and $4.53[4.40,4.67], \mathcal{N}=658$ east of the 100 th meridian) with even fewer in northern Canada $(1.64[1.51,1.77]$, $\mathcal{N}=310$ north of the 49th parallel and 4.2 [4.11, $4.31], \mathcal{N}=1,029$ south of the 49 th parallel $\mathrm{l}$.

\section{Methods}

\section{Field methods of the BBS}

BBSs are conducted along roadside survey routes composed of 50 independent stops, each stop located $800 \mathrm{~m}(0.5 \mathrm{mi})$ apart. Routes are surveyed once annually by an observer, generally a volunteer, who can identify birds by both sight and song. The observer selects a morning in June to conduct the survey (dates in late May are permissible in southern states and in early July in northern provinces); observers are encouraged but not required to be consistent among years in date chosen to survey the route. The survey commences at a pre-established start time (30 min before local sunrise) and the 


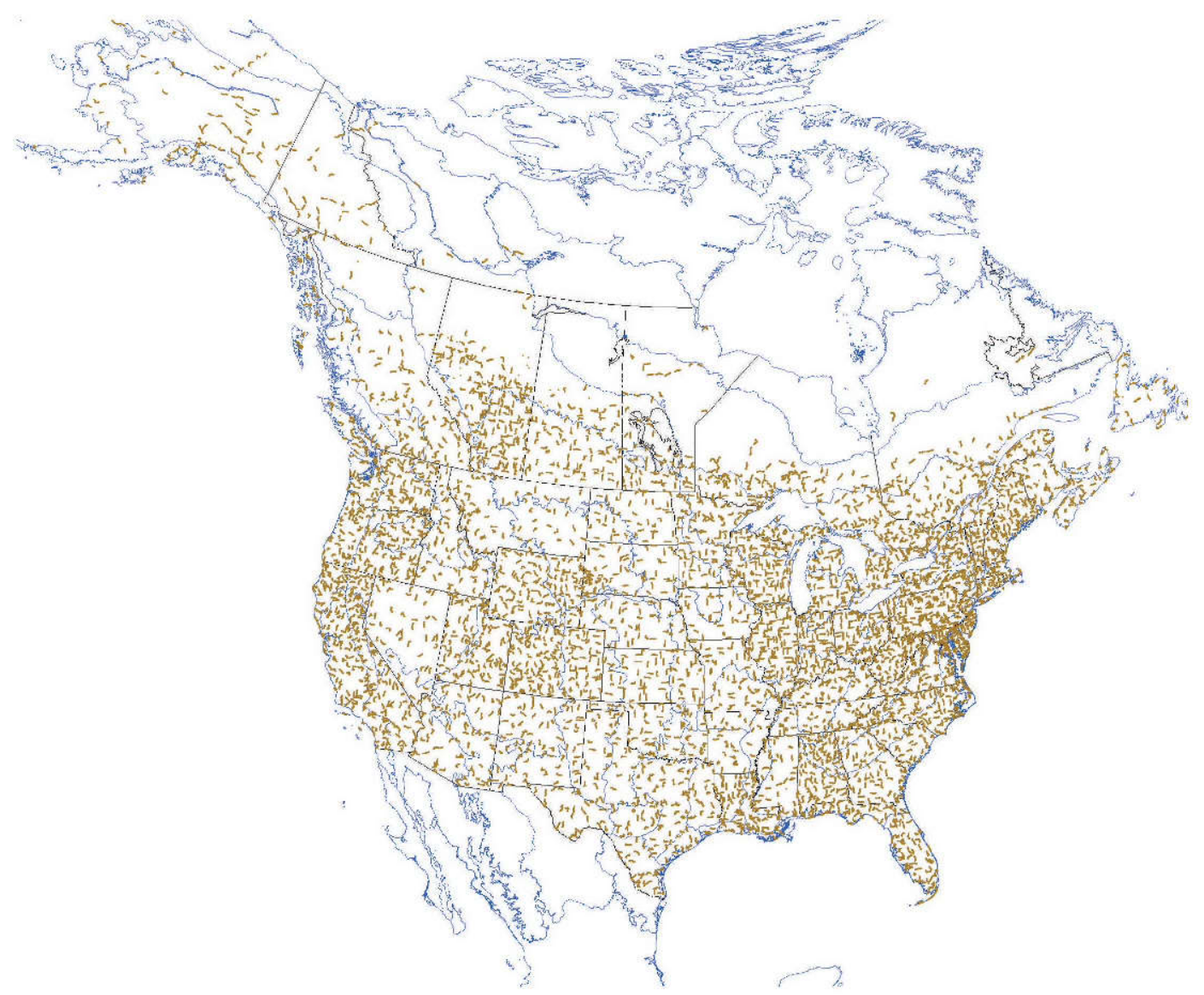

Figure 1. Map of route locations in the continental United States and southern Canada.

observer progresses to each stop in sequence, parking in a safe pull-off at each. Route maps are provided to observers to assist them in finding stops, along with written stop descriptions and GPS locations on some routes (Figure 2).

At each stop, the observer exits the vehicle and conducts a 3-min count of all birds heard and those seen within a $400-\mathrm{m}(0.25-\mathrm{mi})$ radius around the point. The observers record data on data sheets provided to them (Figure 3). The same stop locations are surveyed in subsequent years to ensure consistency in sampling, although stops and routes are occasionally relocated for reasons related to safety or access. Supplemental information including weather variables, disturbance (e.g., number of cars that pass the stop during the count period), and other data are also collected during the survey.

After conducting the surveys, observers submit their data to the respective national BBS oflices, where the data are then processed into both raw and summarized formats for public release via the internet. These data, the protocols for conducting the survey, and additional details regarding the survey are available on the BBS operations website (www.pwrc.usgs.gov/bbs/).

\section{Analysis of population change from BBS data}

Constraints on estimation of population change and historical analyses. Statistical analysis of BBS data can be controversial because complications associated with the nature of the count data and the scale of the survey limit the application of standard sample survey methods (e.g., Sauer et al. 2003). The survey routes sample local populations, and inference regarding population change at regional scales requires accommodation for 1) repeated counts of the survey over years on routes, 2) inequities in numbers of samples among regions, 3) missing data on routes, and (4) changes in the BBS index associated with changes in detectability. The issue of detectability and attendant consequences for inference regarding population change have been a source of controversy from the start of the BBS. Because observers miss a portion of birds when counting, and no means exist in the present protocol 


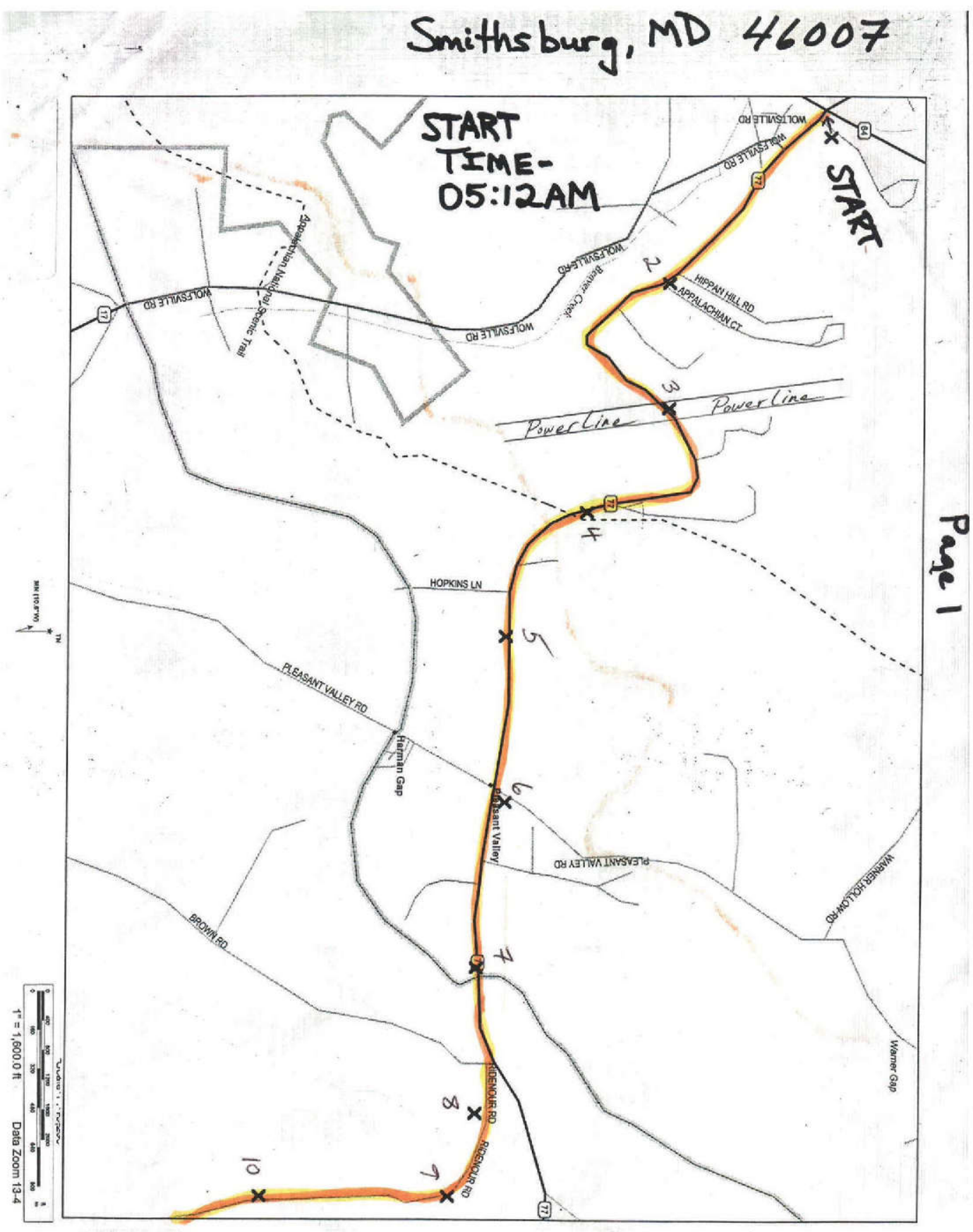

Figure 2. Stop locations on field map used in Breeding Bird Survey.

to estimate directly the fraction of birds missed, controlling for factors that influence the proportion of birds counted is a critical component of the analysis. Observer differences in counting ability are well known to influence detectability (e.g., Sauer et al. 1994; Kendall et al. 1996), and most analyses of BBS data have controlled for observer effects on counts (e.g., Sauer et al. 2008a).
Innovations in analyses of BBS data reflect the advances in computers and statistical methods over the period 19662011 . In early years of the survey, file storage and computational limitations constrained analyses to methods such as route regression that could be implemented on available computers. Modern computer-intensive approaches such as the hierarchical models presented here provide many 


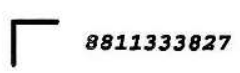

Date $(\mathrm{mm} / \mathrm{dd} / \mathrm{y} / \mathrm{y} y)$

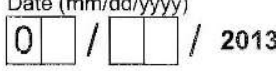

$0 / / \square / 2013$

Species

Canada Goose

Mallard

Northern Bobwhite

Black Vulture

Turkey Vulture

Red-shouldered Hawk

Killdeer

Mourning Dove

Yellow-bilied Cuckoo

Chimney Swift

Red-bel Woodpecker

Downy Woodpecker

"Yel-shafted" Flicker

E Wood Pewee

Acadian Flycatcher

Eastern Phoebe

Grt Crest Flycatcher

Eastern Kingbird

White-eyed Vireo

Yellow-throated Vireo

Red-eyed Vireo

Blue Jay

American Crow

Purple Martin

Barn Swallow

Carolina Chickadee

Tufted Titmouse

Wh-breast Nuthatch

Carolina Wren

Blue-gry Gnatcatcher

Eastern Bluebird

Wood Thrush

American Robin

Gray Catbird

Northern Mockingbird

Brown Thrasher

European Starling

2137

VEHICLES
Excessive Noise:

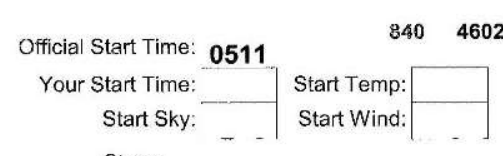

Stops
46029 HUGHESVILLE

Observer's Name:
101

Stops

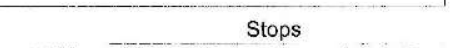


"comparable" over time (i.e., the routes that were consistently surveyed by a single observer). Unfortunately, methods that estimate change from ratios of counts at different times from small samples of comparable routes produce biased estimates (Geissler and Noon 1981). Geissler and Noon (1981) suggested a route-regression analysis, in which linear regression is used to estimate change on individual survey routes and regional trends are computed as an average of these route-change estimates. In early applications (Robbins et al. 1986; Geissler and Sauer 1990), route regression was based on a normal regression with natural-logarithm transformed counts with a 0.5 constant added to accommodate zero counts. However, count data from the BBS are more naturally modeled as a generalized linear model, and Link and Sauer (1994) defined a Poisson regression with log links fit using estimating equations. In both analyses the goal was to estimate rate of change (the slope associated with time), with year and categorical observer data as predictors of the counts. The analysis controlled for observer effects by allowing a different intercept for each observer in the analysis (Link and Sauer 1994). Interval-specific rate of change (trend) for a region was estimated as a weighted average of individual route-slopes for the interval of interest, with mean abundance and survey consistency used as routespecific weights and an area weight included to accommodate regional differences in sample frames in multistrata analyses. Variances of these trend estimates were estimated by bootstrapping. See Geissler and Sauer (1990) and Link and Sauer (1994) for additional information about the routeregression method and the weighting factors. Additional analyses estimated annual indexes from residual variation associated with yearly data around the predicted trends (Sauer and Geissler 1990).

Route regression proved to be a robust approach for estimation of population change (Thomas 1996) but had clear limitations. Although convenient computationally, the route-by-route summaries of change had no direct method to control for withininterval variation in the quality of information. Trends could be estimated for a region even if most of the route data were collected during the later years of the interval. Because there was no way to determine whether route data in a region adequately represented the interval, a trend may have been based on a preponderance of data from early or late in the interval. The weightings, although constructed to permit estimation of change for the total population, were criticized because the weights were ad hoc approximations of unknown quantities (ter Braak et al. 1994). Estimation in route regression was focused on trend, and annual indexes were computed as residuals of the estimated trends (Sauer and Geissler 1990), hence annual indexes were also subject to these criticisms. Although a modified version of Poisson-based route regression (Link and Sauer 1994) is used to estimate local trend for mapping (see Population Change Maps), regional analyses results are now based on hierarchical models.

Hierarchical model analysis. Hierarchical models provide a comprehensive framework for estimating population change and annual indexes of abundance from BBS data. The hierarchical models we use are a class of generalized linear mixed models that permit year, stratum, and observer effects to be governed by parameters that are random variables. This hierarchical structure allows us to model the influence of regions, observers, and other factors on the distributions of the parameters influencing counts, rather than on the individual counts themselves. Using these models, we can formulate regional summaries in terms of model parameters, avoiding the ad hoc weightings used in the routeregression approach. See Link and Sauer (2002) and Sauer and Link (2002) for details of these analyses and the conceptual issues associated with regional models of bird population change.

Hierarchical models are often fit using Bayesian methods, in which inference is based on the posterior distributions of parameters. Bayesian analyses require specification of prior distributions of parameters and the sampling distributions of the data. Although most realistic Bayesian analyses are difficult to implement, simulation-based Markov chain Monte Carlo methods (MCMC; Lunn et al. 2000) can be used to approximate the posterior distributions used in Bayesian inference. Using MGMC, posterior distributions and associated means, medians, and credible intervals (Bayesian confidence intervals) can be calculated iteratively for parameters of interest from many complicated models. Link and Barker (2010) discussed the methods and philosophical basis of Bayesian inference.

In the BBS hierarchical model, counts $Y_{i, j,}$ (indexed by $i$ for stratum, $j$ for unique combinations of route and observer, and $t$ for year) are assumed to be independent Poisson random variables with means $\lambda_{i, j, t}$ that can be described by log-linear functions of explanatory variables,

$$
\begin{aligned}
\log \left(\lambda_{i, j, t}\right)= & S_{i}+\beta_{i}\left(t-t^{*}\right)+ \\
& \omega_{j(i)}+\gamma_{i, t}+\eta I(j, t)+\varepsilon_{i, j, t}
\end{aligned}
$$

which are stratum-specific intercepts $(S)$ and slopes $(\beta)$, along with effects for observer/route combinations $(\omega)$, year $(\gamma)$, start-up $(\eta$, with indicator $I(j, l)$ that takes value 1 for an observer's first year of survey on a route and 0 otherwise), and overdispersion effects $(\varepsilon)$. The model requires specification of prior distributions for parameters. In our analysis, $S_{i}$ and $\beta_{i}$ are assigned diffuse (essentially flat) normal prior distributions, and other effects are specified as having mean zero normal distributions. 
Observer route effects $(\omega)$ are identically distributed with common variance $\sigma_{\omega}^{2}$ and overdispersion effects $(\varepsilon)$ are identically distributed with common variance $\sigma_{\varepsilon}^{2}$. Variance of the year effects $(\gamma)$ is allowed to vary among strata $\left(\sigma_{\gamma, i}^{2}\right)$. All variances are assigned flat inverse gamma prior distributions.

From the model parameters, annual indexes of abundance and trend are defined as derived parameters. Stratum-specific annual indexes of abundance $\left\langle n_{i, t}\right.$, an index to the number of birds per route in stratum $i$ at year $t$ ) incorporate summed and exponentiated stratum effects, stratum-specific trend and year effects, and associated variance components added to accommodate asymmetries in the lognormal distribution:

$$
\begin{aligned}
& n_{i, t}= \\
& \quad \exp \left(S_{i}+\beta_{i\left(t-t^{*}\right)}+\gamma_{i, t}+0.5 \sigma_{\omega}^{2}+0.5 \sigma_{\varepsilon}^{2}\right)
\end{aligned}
$$

Stratum totals are $\mathcal{N}_{i, t}=A_{i} n_{i, t}$, where $A_{i}$ is the area of the stratum. To obtain indexes for larger areas (groups of strata, e.g., states or countries), we sum the $\mathcal{N}_{i, t}$ over the relevant $i$. For presentation, composite indexes $\mathcal{N}_{t}$ are scaled by the total areas, obtaining a summary on the scale of birds per route, $n_{t}=N_{t} / \sum_{i} A_{i}$. The strata are the regions formed by the intersection of Bird Conservation Regions (BCRs; e.g., Sauer et al. 2003; see Population Change Summary) within states or provinces. For summary, results from these areas are combined to provide indexes at the scale of states, provinces, BCRs, and the entire survey area.

We define trend as an interval-specific geometric mean of proportional changes in population size, expressed as a percentage (c.., Link and Sauer 1998). Thus the trend from year $t_{a}$ to year $t_{b}$ for stratum $i$ is $100\left(B_{i}-1\right) \%$, where

$$
B_{i}=\left\{\frac{n_{i, t_{b}}}{n_{i, t_{a}}}\right\}^{\frac{1}{t_{b}-t_{a}}}
$$

The composite trend $\bar{B}$ is calculated analogously as $100(\bar{B}-1) \%$, using the composite indexes $N_{t}=\sum_{i} N_{i, t}$

$$
\bar{B}=\left\{\frac{N_{t_{b}}}{N_{t_{\alpha}}}\right\}^{\frac{1}{t_{b}-t_{a}}}
$$

This definition of trend is interval specific and is applicable for estimation of change for any interval. However, many alternative definitions of trend exist, and some investigators prefer a definition of trend as the slope of a regression line through annual indexes (e.g., Thomas et al. 2004). Using estimates from our model, we calculate this alternative estimate of trend as the slope of a linear regression with time as a predictor and log-transformed annual indexes as the dependent variable. This definition of trend is easily implemented as a derived statistic in the MCMC summaries by calculating a linear regression through the annual indexes derived from each itcration and calculating the percentage change from the estimated slope parameter associated with year. As with other posterior distributions, median slopes and credible intervals are calculated directly from the MCMC results.

The program WinBUGS (Lumn et al. 2000) was used to fit this model, to conduct the MCMC analysis, to evaluate summary statistics to determine when the Markov Chains are converging, and to summarize results. MCMG produces Markov chains that sample the posterior distribution once they become stationary. We conducted the analysis for at least 20,000 iterations to ensure stationary results, and then conducted another 20,000 iterations to obtain results for estimating the posterior distributions. Some species required additional iterations before usable estimates were obtained; for others, the large data sets proved diflicult to manage and we could only summarize 10,000 replicates. For summary, we "thinned' the resulting chains by a factor of 2 (i.e., using every second observation for calculating estimates and credible intervals). We also output the MCMC replicates and used them to compute regional summaries using FORTRAN programs.

\section{Population change summary}

Trend and annual index results are the primary summary information for species from BBS analyses. Here, we present long-term composite trend results $(\bar{B})$, for the intervals 1966 to 2011 and 2001 to 2011 . Since the survey was implemented at different times in different regions, trend estimates and indexes were computed using the first year in which data were available for the species; that is, western species with no data prior to 1968 have trend estimates based on the interval 1968 2011. A regression-based trend estimate is provided for comparison to the long-term trend results. Annual indexes $\left\langle n_{i}\right)$ are estimated at the survey-wide scale; the birds/route scaling of these indexes is not interpretable as an absolute abundance because it is not associated with a known area (Thogmartin et al. 2006).

We use BCRs as components of strata (Sauer et al. 2003; Sauer and Iink 2011). However, the BBS was originally stratified and coordinated within states and provinces, and observation of the map of route locations (Figure 1) indicates that states and provinces vary greally in number of survey routes per unit area. To accommodate this state-specific variation in samples per unit area, we retained states and provinces as a component of the stratification. Consequently, BCRs within states or provinces form our primary strata, and we aggregated these regions 
to estimate composite trends within states, provinces, BCRs, and larger-scale regions.

Visualization of trends across regions is complicated by the large differences in precision among the regions. For each species, we estimated trends from 1966 to 2011 for state and provinces and for BCRs, and we summarize results in figures that document the estimated trend and 95\% CI, using a hierarchical model to order the trends by magnitude and estimate number of regions with decreasing populations (Sauer and Link 2002).

The hierarchical model for estimation of population change requires sufficient samples across the region and time period of interest to allow estimation of the time series, and occasionally regions with limited data either will not converge or will provide extremely imprecise estimated trends. To limit the influence of these regions on the overall analysis, we screen composite summaries to remove regions that provide little information but greatly increase the size of the credible intervals (Sauer and Link 2011). Regions with very small samples, or with data that did not span the interval of interest, produced very imprecise results, and inclusion of these results occasionally led to extremely imprecise regional estimates. We identify regional estimates that should be viewed with concern using quality criteria based on sample sizes and precision as indicated by large credible intervals (Sauer et al. 2011). Sample sizes are defined in terms of number of random BBS routes on which the species was encountered. A small number of nonrandom routes exist in the survey database but were not used in the analysis. Small sample sizes $(<50)$ are flagged for caution. Very small samples $(<14)$ are llagged as possibly unreliable. We classify estimated trends as imprecise if their credible intervals are sufficiently wide that a median change of $3 \%$ per year change would include 0 (i.e., $0.5\left[\mathrm{CI}_{\mathrm{u}}-\mathrm{CI}_{1}\right]>3$ ). We define extremely imprecise trends as those whose credible intervals are sufficiently wide that a median change of $5 \%$ per year change would include 0 .

\section{Maps of relative abundance}

Mapping relative abundance from BBS data has been of interest from the start of the survey, and several generations of maps have been provided to users via publications and the internet (e.g., Robbins et al. 1986; Sauer et al. 2011). Here, we update these maps using current data to model regional patterns of abundance within the boundaries of the surveyed area. Isaaks and Srivastava (1989:42) suggest that summary contour maps be viewed "as helpful qualitative displays with questionable quantitative significance." Their context of discussion was geological data, but the comment is likely at least as relevant for maps of bird survey data from the BBS.
Many investigators have used bird survey data to develop contour maps of bird abundance based on mean counts on survey routes. Root (1988) provided a grid of smoothed relative abundances for species observed on Christmas Bird Counts. Sauer and Droege (1990) mapped relative abundances of eastern bluebirds Sialia sialis just after severe winters in the mid-1970s and after their populations returned to prewinter levels. Relative abundance maps have also been used to document the ranges of species (e.g., Droege and Sauer 1990; Sauer et al. 1995). See Sauer et al. (1995) for applications and discussions regarding mapping of survey data.

We present maps as descriptive summaries of current relative abundance over space. These maps are based on simple averages of counts on routes over time. Although similar data have been used as the basis of population estimates from BBS data, no method exists to control for observer differences in counting ability or for other factors such as roadsidecounting effects, time-of-day effects, or speciesspecific eflective survey areas (Thogmartin et al. 2006). These factors add imprecision and possible bias in estimation of route-specific and regional abundance (Sauer et al. 1994). BBS data are edited to remove data that are of questionable quality or that represent birds thought to be migrating rather than breeding; edges of ranges from these maps thus exclude observations of birds considered to be nonbreeding.

To construct the maps, we used the center points of BBS routes, estimated as the midpoints of digitized route paths (Sauer et al. 2011), as the geographic location of the survey route. Although BBS routes meander over $39.4 \mathrm{~km}$, center points of route paths have been used to characterize route locations in geographic analyses (e.g., Flather and Sauer 1996). Current relative abundance of birds of each species on the routes was estimated as an average of counts on the route from the interval 2007 2011. We used inverse distancing (Isaaks and Srivastava 1989) to interpolate estimated abundances for the map. This procedure estimates the abundance at a location as a distance-weighted average of counts from nearby survey routes. The distance weighting places more influence on nearby routes. For each point on an evenly spaced grid of points overlaid on the survey area, we used inverse distancing to estimate relative abundance of a species based on data from the nearest 15 survey routes, and then displayed the estimated abundances for each surrounding square cell in the grid as our map. The grid was created in Arc/Info (Environmental Systems Research Institute 1991) with grid cells having sides of length $21,475 \mathrm{~m}$. We categorized relative abundances as: 0.05 to $1,>1$ to $3,>3$ to $10,>10$ to $30,>30$ to 100 , and $>100$ birds per route, and shaded the map by succes- 
sively darker reds in each category. The minimum level of 0.05 was chosen as the edge-of-range index after some comparisons of contours with known edges of ranges (S. Droege and D. Bystrak, USGS Patuxent Wildlife Research Center, personal communication), and the larger cut-points were chosen as a series of powers of 3 , rounded up for ease of presentation. To prevent extrapolation beyond the area of consistent data, a northern edge of the surveyed area was defined by buffering routes on the northern edge of the survey area and defining the edge as the perimeter of the polygon formed by the overlapping polygons (cf., Sauer and Link 2011).

\section{Population change maps}

As a summary of spatial pattern in the data, we estimated population change maps to provide a simplified visual alternative to the more rigorous quantitative estimates of regional change provided by hierarchical models. Population change maps were also based on predictions at the grid center points. For each species, we estimated population change for a grid cell using a route regression analysis on nearby routes with data. Population change was estimated on each route using estimating equations, and grid-cell trends were estimated as an abundance- and precision-weighted average of trend estimates from the nearest 15 routes. Estimated population change (percent per year) was categorized as $<-1.5,-1.5$ to $-0.25,>-0.25$ to 0.25 , $>0.25$ to 1.5 , and $>1.51$. As this procedure will not provide results that are constrained to edges of species' ranges, we chose to truncate population change maps to grid cells where the estimated abundance based on data from 1993 to 2011 was $>0.05$. Use of abundance data from the longer interval allowed for depiction of trends from areas where the species may no longer occur.

We note that more sophisticated methods of spatial mapping are available (e.g., Thogmartin et al. 2004). These methods have not yet been fully implemented for BBS data, primarily due to logistical limitations. We are presently evaluating methods for estimating trends for spatial models that use a grid-based spatial structure similar to that used in our inverse-distancing analysis (F. Bled, Colorado State University, personal communication).

\section{Proportion of species' range in the BBS area}

We used the relative abundance map of each species to estimate the proportion of its breeding range covered by the BBS. We developed a northern edge of the surveyed BBS area by buffering the center point of BBS routes with a 12.5-mi circle and defining the edge as an arc with nodes defined as the northern edge of these buffers. This edge appears on our summary maps; the area to the north of the survey region is stippled on the maps. The southern edge of the survey was defined as the southern border of the contiguous United States.

We overlaid the BBS abundance maps on breeding range maps for the western hemisphere prepared by NatureServe (Ridgely et al. 2007; www. natureserve.org/getData/birdMaps.jsp). The proportion of the total breeding and resident range covered by the BBS was calculated. Because the NatureServe maps do not contain relative abundance information, we could not calculate the proportion of the total species' population surveyed by the BBS. A reviewer has pointed out that NatureServe maps are occasionally inaccurate; metadata are available at http://www.natureserve. org/getData/Metadata_Birds_ver_3.0_Oct_07.pdf, but we caution that for some species (e.g., the coastal species such as pelagic cormorant Phalacrocorax pelagicus) and for the grouped species, these number are likely to be imprecise.

\section{Classification of species into groups}

The United States "State of the Birds" Report (U.S. North American Bird Conservation Initiative [NABC] Committee 2009) used composite summaries of population change for groups of bird species as indicators of environmental health. They (U.S. NABCI Committee 2009) categorized bird species by major habitats (aridland; eastern, western, boreal, and subtropical forest; grassland; urban and suburban; wetland; and marsh). For each habitat an inclusive list of species occurring in the habitat was developed; for many of the habitats obligate species that primarily used the habitat were also defined. Widespread species that occur in three or more major habitats were categorized as generalists. Birds were also grouped by migration status: permanent residents, temperate migrants, and neotropical migrants. Finally, exotic (nonnative) species were considered as a group. See the Report (U.S. NABCI Committee 2009) or the State of the Birds Website (www.stateofthebirds.org) for additional information on these groups.

\section{Composite summary by species groups}

For each group of species, we constructed a composite summary of population change using a method similar to that described by Gregory et al. (2005). Gregory et al. (2005) defined a composite summary as a geometric mean of scaled (to a base year) population trajectories for species in the group. As BBS results vary greatly in quality of information, simple averages of estimates are dominated by extreme, yet imprecise, estimates (e.g., Sauer and Link 2002). We modified a hierarchical model described by Sauer and Link (2002) to summarize collections of trend estimates and used this to estimate the mean of the collection of trends. This 
model has the benefit that the mean is based on the parameters, not on the often imprecise estimates.

To be consistent with the Gregory et al. (2005) long-term summaries of change (rather than yearly changes as defined in Sauer and Link 2002), the model assumes that the logarithms of the estimates of change parameters $\left(\hat{B}_{s}\right)$, for $s=1, \ldots, n$ species are normally distributed, \{i.e., $\left[\ln \left(\hat{\beta}_{s} \mid \beta_{s}, \sigma_{s}^{2}\right]=\mathcal{N} \ln \left(\beta_{s}\right)\right.$, $\left.\left.\sigma^{2}{ }_{s}\right]\right\}$; and distributions for the $\beta_{s}$ are lognormal $\left\{\left[\ln \left(\beta_{s}\right) \mid \mu, \tau^{2}\right]=\mathcal{N}\left(\mu, \tau^{2}\right)\right\}$. Note that this model is applied to each year; year subscripts are suppressed. We used this model in a Bayesian analysis, assuming noninformative priors for the $\mu$ and $\tau$ parameters. We applied the model to data for each year starting from a base year of 1968 for each group of species and estimated the posterior distributions of the exponentiated trend parameters. We present medians and percentile credible intervals of the posterior distributions of $\exp (\mu)$ for each year as the composite change from the base year to that year. We plot these results as the composite summary for each group.

See Link and Barker (2010:85 93) for an informative discussion regarding use of hierarchical models to estimate number of regions with increasing populations. While these methods were developed for ranking species rather than regions within species, we applied them here as an exploratory tool to permit readers to evaluate regional consistency of declines.

\section{Presentation of results}

Species accounts. We integrate and present information for individual species as species accounts (Appendix A). Species Accounts provide summary statistics and visually oriented summaries of overall pattern, via l) general information including proportion of the species' range that is surveyed; 2) population trend results from 1966 2011 and 2001-2011; 3) abundance maps; 4) population change graphs; 5) population change maps; 6) state and provincial population trend summaries from 1966 to 2011; and 7) BCR population trend summaries from 1966 to 2011. For the regional summaries (items 6 and 7), we provide graphics of trend results ranked by magnitude of trend, excluding regions with highly imprecise estimates ([half-width of $\mathrm{CI}]>5$ ) or with limited samples $(N<5$ routes in the region).

Species group summaries. Species group summaries (Appendix B) are presented for indicator and migration status species groups. For each species group, we present 1) overview information on the group (geographic scope, $\mathcal{N}$ of species, percentage of species for which BBS provided information, and average percent ranges of the analyzed species in the BBS survey area); 2) a population change summary detailing the total percentage composite change over
$42 \mathrm{y}$ with associated credible interval; 3) an indicator graph of composite total change, the yearly $\exp (\mu)$ as already described; and 4) a graphical summary and listing of 1966-2011 trend estimates for each of the constituent species.

Summary of individual species results by taxonomic grouping. We provide overviews of population change by taxonomic groupings at the level of subfamily or family. We list species analyzed for the group, describe notable long-term, survey-wide trends, and provide a brief commentary on the value of the survey for the taxa. We also note species that have been identified as being of conservation concern, using the inclusive definition of conservation concern used in the State of the Birds 2009 report (U.S. NABCI Committee 2009). We adopt the convention of referring to positive (or negative) estimates of change if the 1966-2011 change estimates are $>0$ (or $<0$ ); we consider the results to be significant if the credible intervals of the interval estimates do not overlap 0. Taxonomy and order of presentation follow the American Ornithologists' Union Check-list of North American Birds 52nd Supplement (Chesser et al. 2011).

Taxonomic changes over the BBS survey period introduce complications for management and summary of the BBS. In particular, several species have been split into multiple species by taxonomists. For some of these species, early data collected from areas of sympatry cannot be discriminated adequately to permit contemporary range-wide species-level analyses, and updating the database and analyses can be time-consuming and controversial. Western and Clark's grebes, Aechmophorus occidentalis and Aechmophomes clarkii, respectively, and Cordilleran and Pacific-slope flycatchers, Empidonax occidentalis and Empidonax difficitis, respectively, are presently analyzed as single taxa. We also produce species accounts for two groups of species, for which individual species results are also presented: alder and willow flycatchers, Empidonax alnorum and Empidonax traillii, respectively (formerly considered to be a single species named "Traill's flycatcher" Empidonax (raillii), and yellow-bellied, red-naped, and red-breasted sapsuckers, Sphyrapicus varius, Sphyrapicus nuchalis, and Sphyrapicus ruber, respectively.

\section{Results}

\section{Summary of individual species results}

Appendix A provides accounts for the 426 species and two species groups. Over the 19662011 period, 242 of the 426 species we considered in our analysis had negative trend estimates (Figure 4). The Bayesian estimate of percentage of declining species from 1966 to 2011 (Sauer and Link 2002) was $56.8 \%$ $(52.3,61.0)$. Of these, 153 species experienced significant declines (i.e., those with credible intervals that did not include 0), and 90 of the 184 species 


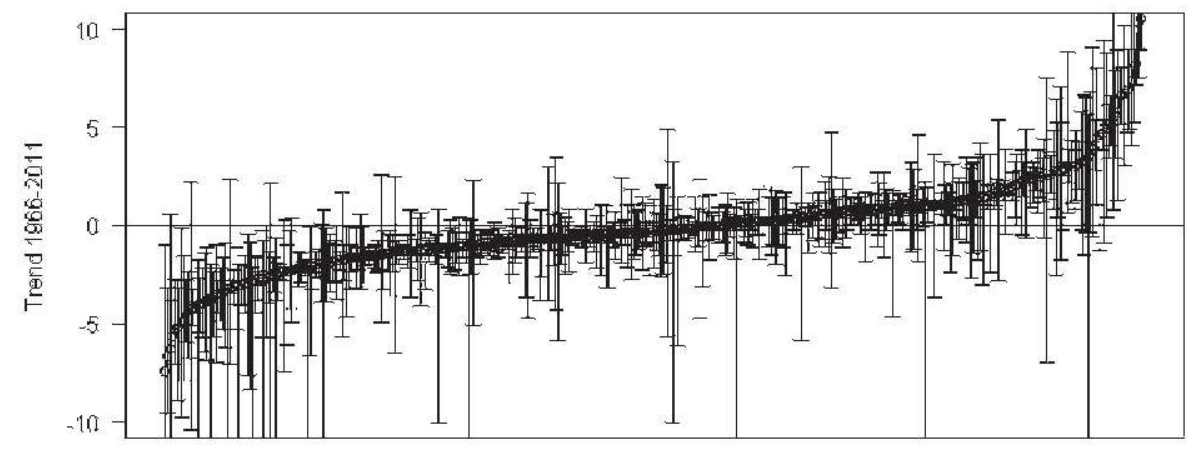

Fiankec Trend

Figure 4. Estimated annual trends and $95 \%$ credible intervals for 426 species of North American birds for the interval 1966-2011, ranked from most declining to most increasing. For clarity of presentation, individual species are not identified.

with positive trend estimates experienced significant increases. Over the 2001-2011 interval, 146 of the 426 species we considered in our analysis had negative trend estimates (Figure 5), and 58 species experienced significant declines (i.e., those with credible intervals that did not include 0 ). Bayesian estimate of percentage of declining species for 2001 to 2011 was $40.1 \%(34.3,46.2)$. Over the same interval, $272(64 \%)$ of the 426 species had positive trend estimates, and 116 of these species experienced significant increases.

\section{Taxonomic summaries}

Whistling-ducks. Order: Anseriformes, Family: Anatidae, Subfamily: Dendrocggninae (black-bellied whistling-duck Dendrocygna autumnatis, fulvous whisling-duck Dendrocygna bicolor)
Limited data exist on whistling-ducks from the BBS, and the small portion of their breeding ranges $(2.1 \%)$ contained in the United States are likely of limited value in assessing the overall population status of the species. In the BBS survey area, both species show positive estimates of change between 1966 and 2011, although trends were significant only for the black-bellied whisling-duck.

Geese and swans. Order: Anseriformes, Family: Anatidae, Subfamily: Anserinae (Canada goose Branta canadensis, mute swan Cygnus olor)

Both Canada goose and mute swan are increasing in the BBS survey area, and for both species the BBS analysis indicates that positive trends occur in all states, provinces, and BCRs. The BBS clearly shows the dramatic and significant increase of Canada goose in the United States and southern Canada.

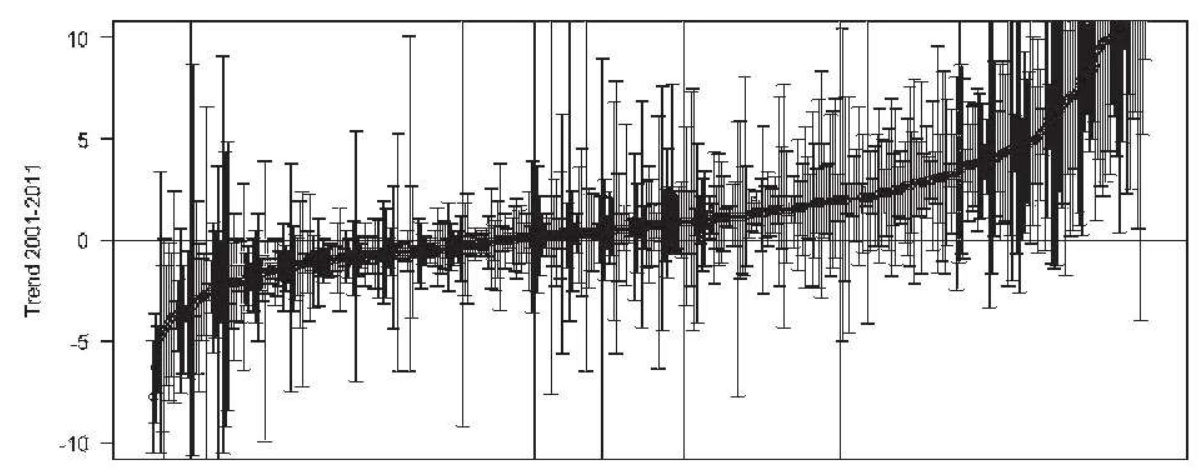

Reanket Trent

Figure 5. Estimated trends and $95 \%$ credible intervals for 426 species of North American birds for the interval 20012011, ranked from most declining to most increasing. For clarity of presentation, individual species are not identified. 
Mute swan results reflect the imprecision associated with low observation rates.

Ducks. Order: Anseriformes, Family: Anatidae, Subfamily: Anainae (wood duck Aix sponsa, gadwall Anas strepera, American wigeon Anas americana, American black duck Anas rubripes, mallard Anas plalyrlynchos, motuled duck Anas fulvigula, blue-winged teal Anas discors, cinnamon teal Anas cyanoptera, northern shoveler Anas clypeala, northern pintail Anas acuta, green-winged teal Anas crecca, canvasback Aythya valisineria, redhead Aythya americana, ring-necked duck Aythya collaris, lesser scaup Aythya affinis, bulllehead Bucephala albeola, common goldeneye Bucephala clangula, Barrow's goldeneye Bucephala islandica, hooded merganser Lophodytes cucullatus, common merganser Mergus merganser, red-breasted merganser Mergus serrator, ruddy duck Oxyura jamaicensis)

We present results for 22 species of ducks. On average $55 \%$ of the breeding ranges of these species are covered by the BBS. However, the wetland habitats they frequent are often poorly represented along BBS routes, and hence the species show low relative abundances; seven show imprecise surveywide trend estimates. The U.S. Fish and Wildlife Service and Canadian Wildlife Service conduct more comprehensive waterfowl surveys of the primary breeding ranges of these species, but BBS data are useful in showing regional population changes in portions of the continental United States not covered by the extensive surveys. In particular, wood duck results from the BBS are used as the primary source of population status information for that species. The BBS covers $96 \%$ of wood duck breeding range and documents significant increases from 1966 to 2011. Increases are also noted for gadwall, for which $99 \%$ of the breeding range is covered by the survey, and hooded merganser, for which $92 \%$ of the breeding range is covered. Mottled duck, a watchlist species, shows significant declines, due primarily to declines in the western portions of its range. American wigeon, cinnamon teal, and lesser scaup also show significant declines, as does red-breasted merganser according to its very limited data. Northern pintail show declines from the regression trend estimate, but a large increase in the index for 2011 caused the CI for the interval estimate to overlap 0 .

Quail. Order: Galliformes, Family: Odontophoridae (mountain quail Oreortyx pictus, scaled quail Callipepla squamata, California quail Callipepla califomica, Gambel's quail Callipepla gambelii, northern bobwhite Colinus virginianus)

We present survey results for five quail species, which on average have $75 \%$ of their ranges in the BBS survey area. Of the three species of conservation concern, mountain quail appears stable in the BBS analysis, although scaled quail $(-3.1 \% / y)$ and northern bobwhite $(-4.2 \% / y)$ are significantly declining. California quail are significantly increasing $(1.7 \% / y)$, and Gambel's quail appear stable.

Pheasants. Order: Galliformes, Family: Phasianidae (chukar Alectoris chukar, gray partridge Perdix perdix, ring-necked pheasant Phasianus colchicus)

Three exotic pheasant species have their entire (introduced) North American ranges surveyed by the BBS. Ring-necked pheasant and gray partridge are experiencing declines in many states, provinces, and BCRs; overall trends are negative, with a significant decline $(-1.5 \% / y)$ occurring in gray partridge populations. Chukar populations are stable.

Grouse and prairie chickens. Order: Galliformes, Family: Phasianidae, Subfamily: Tetraoninae (ruffed grouse Bonasa umbellus, greater sage-grouse Centrocercus urophasianus, dusky grouse Dendragapus obscurus, sooty grouse Dendragapus fuliginosus, sharp-tailed grouse Tympanuchus phasianellus, greater prairic-chicken Tympanuchus cupido)

The ranges of these grouse are largely covered by the BBS. We do not present results from the limited data available for lesser prairie chicken Tympanuchus pallidicinctus, Gunnison's sage grouse Centrocercus minimus, or ptarmigan species Lagopus spp. Several grouse species are of conservation concern: greater sage-grouse has a declining population with a significant, although imprecisely estimated, trend of $-3.6 \% / y$; sooty grouse is declining significantly at $-1.6 \% / \mathrm{y}$; dusky grouse shows a nonsignificant increase; and greater prairie chicken has a positive, but very imprecise, estimate of population change.

Wild turkey. Order: Galliformes, Family: Phasianidae, Subfamily: Meleagridinae

The BBS indicates significant $(8.4 \% / y)$ increases in the wild turkey Meleagris gallopavo population across the $90 \%$ of its range that falls within the BBS survey area.

Common loon. Order: Gavïformes, Family: Gaziidae

Only $31 \%$ of the range of common loon Gavia immer falls within the BBS survey area, and populations among states, provinces, and BCRs show positive but not significant trends.

Grebes. Order: Podicipediformes, Family: Podicipedidae (pied-billed grebe Podilymbus podiceps, horned grebe Podiceps auritus, red-necked grebe Podiceps grisegena, eared grebe Podiceps nigricollis, western and Clark's grebes [combined]).

The BBS provides information on all grebe species except least grebe Tachybaptus dominicus, although on average only $43 \%$ of their ranges are covered. Clark's grebe is a species of conservation concern, in composite with western grebe the populations are not significantly declining overall although results are imprecise. Horned grebe is significantly declining at $1.8 \% / y$ across the $39 \%$ of the species' range that occurs in the BBS region.

Wood stork. Order: Ciconïformes, Family: Ciconüdae 
Wood stork Mycteria americana is not well monitored by the BBS, with very imprecise results, and $<1 \%$ of the species breeding range occurs in the survey area.

Cormorants. Order: Suliformes, Family: Phalacrocoracidae (double-crested cormorant Phalacrocorax auritus, pelagic cormorant)

We present results for two species of cormorants. Double-crested cormorants are widespread in the contiguous United States and southern Canada and are increasing in $93 \%$ of states, provinces, and BCRs. The BBS covers $74 \%$ of the species' range. Trends for pelagic cormorant are poorly estimated from data from only 20 survey routes.

\section{Anhinga. Order: Suliformes, Family: Anhingidae}

The small part of the anhinga Anhinga anhinga breeding range that falls within the BBS area $(4 \%)$ contains increasing populations, particularly in recent years.

Pelicans. Order: Pelecaniformes, Family: Pelecanidae (American white pelican Pelecanus erythrorhynchos, brown pelican Pelecanus occidentalis)

American white pelican has $88 \%$ of its range in the BBS survey area and has a generally increasing population, although change is imprecisely estimated from BBS data. Brown pelican is a coastal species, and thus BBS data are very limited and imprecisely estimated; however, BBS data also indicate a longterm significant increase for the species of $5.4 \% / y$.

Herons, egrets, and bitterns. Order: Pelecaniformes, Family: Ardeidae (American bittern Botaunus lentiginosus, least bittern Ixobrychus exilis, great blue heron Ardea herodias, great egret Ardea alba, snowy egret Fgretta thula, little blue heron Egretta caenulea, tricolored heron Fgretta tricolor, catle egret Bubulaus ibis, green heron Bulorides virescens, black-crowned night-heron Nycticorax nycticorax, yellowcrowned night-heron Nyctanassa itolacea)

With the exception of reddish egret Egrella nufescens, which is not surveyed by the BBS, these wading birds are well represented in BBS results. On average $40 \%$ of the species' ranges are covered by the BBS. Wetland habitat use and, for some species, colonial nesting habits limit observability from roads; not surprisingly, a few species have very low abundances along survey routes. Significant declines occur in little blue heron $(-1.2 \% / y)$, catle egret $(-1.0 \% / y)$, and green heron $(-1.6 \% / y)$; seven other species have nonsignificant declining populations. Great blue heron $(0.8 \% / y)$ and great egret $(2.5 \% / y)$ show significantly increasing populations.

Ibis. Order: Pelecaniformes, Family: Threskiomithidae, Subfamily: Threskiomilhinae (white ibis Eudocimus albus, glossy ibis Plegadis falcinellus, white-faced ibis Plegadis chihi

Ibis species have all been increasing overall in the BBS survey area, but white ibis and white-faced ibis each have only a quarter of their breeding ranges in the survey area, while glossy ibis has about $44 \%$ of its range in the BBS area. Ibis tend to be seen in relatively large numbers on limited numbers of routes and are also variable over time. This leads to imprecision in results, and white ibis is the only species with relatively precise results. While BBS indexes likely provide a reasonable description of change over time, the large and imprecisely estimated indexes are much larger than mean counts on a route.

Roseate spoonbill. Order: Pelecaniformes, Family: Threskiomithidae, Subfamily: Plataleinae

Although imprecise, BBS results indicate rapidly increasing populations $(7.6 \% / y)$ for the very limited part of the roseate spoonbill Platalea ajaja breeding range $(1.1 \%)$ that falls in the BBS area.

Vultures. Order: Accipitriformes, Family: Calharlidae (black vulture Coragyps alralus, turkey vulture Cathartes aura)

Both vulture species monitored by the BBS have large breeding ranges in the neotropics, and the BBS provides information from the northern edge of their ranges. Black vulture $(4.8 \% / \mathrm{y})$ and turkey vulture $(2.4 \% / y)$ show rapidly and significantly increasing populations in the BBS survey area.

\section{Osprey. Order: Accipitriformes, Family: Pandionidae}

About hall the breeding range of osprey Pandion haliaetus falls into the BBS area, although this waterdependent species is generally encountered at very low abundances. This species has been significantly increasing $(2.5 \% / \mathrm{y})$ across the surveyed area.

Kites, hawks, and eagles. Order: Accipiniformes, Family: Accipitridae (swallow-tailed kite Elanoides forficatus, whitetailed kite Elanus leucurus, Mississippi kite Ictinia mississippiensis, bald eagle Haliaeetus lencocephalus, northern harrier Circus cyaneus, sharp-shinned hawk Accipiler striatus, Cooper's hawk Accipiler cooperï, northern goshawk Accipiler gentilis, Harris's hawk Parabuleo unicinctus, red-shouldered hawk Buteo lineatus, broadwinged hawk Buteo platyplerus, Swainson's hawk Buleo swiansoni, red-tailed hawk Buteo jamaicensis, ferruginous hawk Buteo regalis, golden eagle Aquila chrysaelos)

This heterogeneous group shows a wide variety of population trends. Mississippi kite's range is almost entirely within the BBS region, and it tends to be increasing except in the western part of the range leading to an overall estimate of no change. Swallow-tailed kite is significantly increasing in the $3 \%$ of its range monitored by the BBS, and whitetailed kite shows no change in the $4 \%$ of its range covered by the BBS. Bald eagle, recently removed from the endangered species list, has increased dramatically $(5.4 \% / y)$ over the survey interval although it is still rare on BBS routes. Northern harrier has been significantly declining overall $(-0.9 \% / y)$ although regional variation occurs in its trends. All accipiters are infrequently encountered on BBS routes; Cooper's hawk has $97.4 \%$ of its range in the BBS area and shows a significant $2.4 \%$ / y increase over the survey interval. Among buteos, 
Harris's hawk, the only southwestern species, shows a significant decline $(-1.9 \% / y)$ in the $6 \%$ of its range covered by the BBS. Other buteos show significantly increasing populations survey-wide and have large portions of their ranges within the BBS survey area. Golden eagle shows generally stable populations within the $42 \%$ of its range covered by the BBS.

Crested caracara. Order: Falconiformes, Family: Falconidae Subfamily: Caracarinae

Crested caracara Caracara chemway is another species whose primary breeding distribution is south of the BBS survey area. The species is significantly increasing in Texas and Florida.

Falcons. Order: Falconiformes, Family: Falconidae, Subfamily: Falconinae (American kestrel Falco sparverius, merlin Falco columbarius, peregrine falcon Falco peregrinus, prairie falcon Falco mexicanus)

Of the falcons, American kestrel is the best surveyed by the BBS, having $40 \%$ of its range in the survey area and average relative abundance of about $1 \mathrm{bird} / \mathrm{route}$; its population is significantly declining $(-1.5 \% / y)$ over the sample area. The prairie falcon population is increasing (although not significantly with the interval-based CI) over the $86 \%$ of the range covered by the BBS, although the species is encountered only infrequently $(0.1$ birds/ route). The BBS covers only $30 \%$ of the breeding ranges of peregrine falcon and merlin. Merlins are significantly increasing $(3.1 \% / y)$; peregrine falcon trends are positive, but imprecisely estimated.

Rails, gallinules, and coot. Order: Gniformes, Family: Rallidae (clapper rail Rallus longirostris, king rail Rallus elegans, Virginia rail Rallus limicola, sora Porzana carolina, purple gallinule Porphyrio martinica, common gallinule Gallinula galeala, American coot Fulica americana)

The BBS provides the only long-term information on breeding populations of rails; hence the information is often cited even though the survey is not wellsuited for monitoring these poorly detected marsh birds. Of the four rail species, the significantly declining $(-4.0 \% / y)$ king rail and the nonsignificantly declining clapper rail are of conservation concern. Virginia rail was rarely encountered on the 392 BBS routes from which they have been recorded, while sora has been detected on 989 BBS routes. Both species show positive but nonsignificant trends. Only 25\% of the clapper rail range is in the BBS survey area, although the ranges of the other rail species are well covered $(>69 \%)$ by the BBS. Purple gallinule and common moorhen Gallinula chloropus show nonsignificant population declines in the small part $(<30 \%)$ of their range that occurs in the BBS area. American coot has experienced large population fluctuations during the 1966-2011 BBS period and has no significant trend overall; $77 \%$ of its range is covered by the BBS.
Sandhill crane. Order: Gruiformes, Family: Gruidae, Subfamily: Gruinae

About a third of the sandhill crane Grus canadensis breeding range is monitored by the BBS, which shows a significant $5.3 \% / y$ long-term increase for the species.

Plovers. Order: Charadrïformes, Family: Charadrïdae, Subfamily: Charadrïnae (killdeer Charadrius vociferus, mountain plover Charadrius montanus)

Both killdeer $(-1.2 \% / y)$ and mountain plover $(-3.0 \% / y)$ show significant declines over the 1966 2011 period, although for both species the declines appear to be less severe during the recent period (2001 2011). Killdeer is likely well monitored over the $73 \%$ of its range that falls in the BBS area. Even though their entire breeding range is in the BBS area, mountain plover is considered to be poorly monitored by the BBS, with imprecise results due largely to small sample sizes and poor coverage of their habitats from roadsides (U.S. Department of the Interior 2011).

Stilt and avocet. Order: Charadrïformes, Family: Recurvirostridae (black-necked stilt Himanlopus mexicanus, American avocet Recurvirostra americana)

Black-necked stilt has increased significantly $(2.8 \% / y)$ in the $13 \%$ of its range that falls in the BBS area; American avocet is generally stable over the $93 \%$ of its range that is monitored by the BBS.

Sandpipers. Order: Charadrïformes, Family: Scolopacidae, Subfamily: Scolopacinae (spotted sandpiper Actilis macularius, solitary sandpiper Tringa solitaria, greater yellowlegs Tringa melanoleuca, willet Tringa semipalmata, lesser yellowlegs Tringa flaxipes, upland sandpiper Bartramia longicauda, long-billed curlew Numenus americanus, marbled godwit Iimosa fedoa, Wilson's snipe Gallinago delicala, American woodcock)

Greater yellowlegs and lesser yellowlegs breed primarily outside the BBS area, but the limited data from the BBS for lesser yellowlegs from prairic Canada indicate a significant population decline $(-5.3 \% / y)$ for this species of conservation concern. Solitary sandpiper, also a bird of conservation concern, has similarly limited BBS coverage and very imprecise results. Willet breeds within the BBS region, and its population has been stable during the BBS survey interval. Spotted sandpiper is widespread in the BBS area, which covers $60 \%$ of its range, and is significantly declining $(-1.4 \% / y)$ over most of the surveyed area. Upland sandpiper, longbilled curlew, and marbled godwit are all species of conservation concern, and the BBS covers most of their ranges. BBS indicates generally increasing $(0.5 \% / y)$ upland sandpiper populations over most of the breeding range, and data show no evidence of significant declines for the other species. Half of the Wilson's snipe breeding range is covered by the BBS and, although the survey-wide estimates indicate no change, midcontinent populations of the species are 
increasing while western and eastern populations are declining. American woodcock are rarely encountered on BBS routes, but indications of decline in the regression-based summary of the BBS are consistent with results from the Singing-ground Survey that the U.S. Fish and Wildlife Service and Canadian Wilddife Service conduct each spring for the species (Sauer et al. 2008b).

Wilson's phalarope. Order: Charadriiformes, Family: Scolopacidae, Subfamily: Phalaropodinae

Wilson's phalarope Phalaropus tricolor is encountered on a moderate number of BBS routes over the $93 \%$ of its range occurring in the BBS survey area, and populations appear stable.

Gulls. Order: Charadriiformes, Family: Laridae, Subfamily: Larinae (laughing gull Leucophaeus atricilla, Franklin's gull Leucophaeus pipixcan, ring-billed gull Lanus delawarensis, western gull Larus occidentalis, California gull Lams califormicus, herring gull Iams argentatus, glaucous-winged gull Larus glaucescens, great black-backed gull Larus marimus)

Interpretations of gull data from the BBS tend to be somewhat controversial because these species often have only the margins of their ranges covered by the BBS and birds are found in flocks or as nlyovers, all of which leads to imprecise data. Glaucous-winged gull and great black-backed gull have $<10 \%$ of their range in the BBS area and nonsignificant population trends. Three other species have $<30 \%$ of their ranges in the survey area. Of these, the western gull has very limited data; herring gull appears to be significantly declining overall $(-3.8 \% / y)$, albeit with imprecise estimates; and laughing gull has an increasing population $(2.8 \% / y)$. Of the gull species with $>70 \%$ of their breeding ranges in the BBS area, Franklin's gull shows significant declines $(-4.2 \% / \mathrm{y})$, ring-billed gull shows a significant population increase $(3.0 \% / \mathrm{y})$, and California gull shows a nonsignificant decline.

Terns. Order: Charadrïformes, Family: Laridae, Subfamily: Steminae (least tern Sternula antillanum, gullbilled tern Gelochelidon nilotica, Caspian tern Hydroprogne caspia, black tern Chlidonias niger, common tern Stema himundo, Forster's tern Stema forsteri, royal tern Thalasseus maximus)

Terns are, with one exception, poorly monitored by the BBS. Gull-billed tern, royal tern, and least tern have $<15 \%$ of their breeding ranges covered by the BBS, and have imprecise results. Caspian tern, Forster's tern, and common tern, with ranges covered $48 \%-93 \%$ by the BBS, also have imprecise results. Black tern is the exception because its populations show significant declines over the $>80 \%$ of its range covered by the BBS.

Black skimmer. Order: Charadrïformes, Family: Laridae, Subfamily: Rynchopinae

Black skimmer Rynchops niger, which is a coastal species with only $1 \%$ of its range covered by the
BBS, has very imprecise trend estimates from BBS data.

Doves and pigeons. Order: Cohmbiformes, Family: Columbidae (rock pigeon Columba livia, band-tailed pigeon Palagioenas fasciala, Eurasian collared-dove Streptopelia decaocto, white-winged dove Zenaida asiatica, mourning dove, Inca dove Columbina inca, common ground-dove Columbina passerina)

Doves and pigeons are visible species that are easy to detect along BBS routes. Two exotic species are encountered by BBS observers. The rock pigeon is widespread and has been experiencing small $(-1.0 \% / y)$, but significant declines over the BBS interval, although regional results suggest that declines are centered in the eastern United States with a mosaic of increase and declines elsewhere. Eurasian collared-dove is increasing significantly everywhere at extremely high rates, although it has not yet colonized northern parts of the continent. Common ground-dove and Inca dove are southern species with only parts of their ranges in the BBS area, and both of them appear to be increasing at the northern edges. Common ground-dove is declining in Florida but is stable elsewhere; Inca doves are significantly increasing in Texas and Louisiana. Three harvested species are monitored by the BBS and by U.S. Fish and Wildlife Service (USFWS) surveys. Mourning dove is widespread and abundant; BBS indicates an overall decline $(-0.4 \% / y)$ of the species but with increases in the northeastern part of the survey. Band-tailed pigeon is declining significantly $(-2.4 \% / y)$ in the $46 \%$ of its breeding range in the BBS area, and white-winged dove is increasing in most states, but not significantly overall.

Cuckoos. Order: Cuculiformes, Family: Cuculidae, Subfamily: Cuculinae (yellow-billed cuckoo Coccyzus americanus, black-billed cuckoo Coccyzus erythropthalmus)

Populations of both yellow-billed cuckoo $(-1.5 \% /$ y) and black-billed cuckoo $(-3.1 \% / y)$ are significantly declining in the BBS survey area, although estimates from the latter are quite imprecise.

Greater roadrunner. Order: Cuculiformes, Family: Cuculidae, Subfamily: Neomorphinae

Greater roadrunner Geococcyx califormiamus, which has $62 \%$ of its breeding range in the BBS area, shows no significant trend from BBS data.

Groove-billed ani. Order: Cuculiformes, Family: Cuculidae, Subfamily: Crotophaginae

Groove-billed ani Crolophaga sulcirostris has only $4 \%$ of its range in the BBS area (in south Texas), and trends for the species are imprecisely estimated from BBS data.

Barn ow\%. Order: Strigiformes, Family: Tytomidae

Owls are not a target group for the BBS. Except for accidental observations, they generally are only detectable during the first few stops of a BBS route due to their largely nocturnal and crepuscular activity patterns. Barn owls Tyto alba are seen at 
extremely low abundances on a relatively small number of survey routes on the $23 \%$ of their (western hemisphere) range occurring in the survey area. The BBS trend estimates suggest a recent (2001-2011) increase in the species' population.

Typical owts. Order: Strigiformes, Family: Strigidae (western screech-owl Megascops kennicoliii, eastern screech-owl Megascops asio, great horned owl Bubo virginianus, northern pygmy-owl Glaucidium gnoma, burrowing owl Athene cuncularia, barred owl Strix varia, short-eared owl Asio flammeus)

Short-eared owl and burrowing owl are diurnal and hence are the most observable owl species along BBS routes. Both species have only about $30 \%$ of their range in the BBS area; Short-eared owls have fluctuating populations with no significant trend, but burrowing owls are significantly declining $(-1.1 \%$ / y). Eastern screech-owl and western screech-owl are rarely detected on BBS routes; eastern screech-owl has undergone a significant decline $(-1.4 \% / y)$, while the western screech-owl has negative but insignificant trends that are very imprecisely estimated. Northern pygmy-owl is also encountered at very low abundance on BBS routes and shows a nonsignificant positive trend. Barred owl is significantly increasing and has $87 \%$ of its range in the BBS area. Great horned owl is significantly declining in the $40 \%$ of its range in the BBS survey area.

Nighthazeks. Order: Caprimulgiformes, Family: Caprimutgidae, Subfamily: Chordeilinae (lesser nighthawk Chordeiles acutipennis, common nighthawk Chordeiles minor)

Common nighthawk has $75 \%$ of its range in the survey area and is significantly declining $(-2.2 \% / y)$. Lesser nighthawk, a southwestern species, has only $27 \%$ of its range in the BBS survey area and has very imprecisely estimated trends.

Poonwill, Chuck-will's-widow, and whip-poor-will. Order: Caprimulgiformes, Family: Caprimulgidae, Subfamily: Caprimulginae (common poorwill Phalaenoptilus nuttallii, Chuck-will's-widow Caprimulgus carolinensis, eastern whip-poor-will Caprimulgus vociferus

Each of these three nightjars has $>75 \%$ of breeding range within the BBS survey area. The two eastern species, Chuck-will's-widow and whippoor-will, are significantly declining, while common poorwill has no apparent survey-wide trend. Although these species are not active during most of later stops along BBS routes, only the eastern whippoor-will has notably imprecise estimates of population change; that lack of precision is likely due to imprecise estimates during the early years of the survey.

Swifts. Order: Apodiformes, Family: Apodidae, Subfamilies: Cypseloidinae, Chaeturinae, and Apodinae (black swift Cypseloides niger, chimney swift Chaetura pelagica, Vaux's swift Chaelura vauxi, white-throated swift Aeronautes saxatalis)
Black swift is a species of conservation concern. The BBS shows significant decline $(-6.8 \% / y)$ although with imprecise estimates across the 35\% of the species' range in the BBS area. Chimney swif is also declining significantly $(-2.3 \% / y)$, and $>99 \%$ of their range is covered by the BBS. Vaux's swift and white-throated swift show nonsignificant declines over the $53 \%$ and $68 \%$, respectively, of their breeding ranges in the BBS survey area.

Hummingbirds. Order: Apodiformes, Family: Trochitidae, Subfamily: Trochilimae (ruby-throated hummingbird Archilochus colubris, black-chinned hummingbird Archilochus alexandri, Anna's hummingbird Calypte anna, Costa's hummingbird Calypte costae, calliope hummingbird Stellula calliope, broad-tailed hummingbird Selasphorus platycercus, rufous hummingbird Selasphonus nufus, Allen's hummingbird Selasphorus sasin)

These hummingbirds have $83 \%$ of their ranges, on average, in the BBS area. Among the four species surveyed by the BBS that are of conservation concern, two (Rufous hummingbird at $-2.0 \% / y$ and Allen's hummingbird at $-4.5 \% / y$ ) are significantly declining. Among the other species, only broad-tailed hummingbird is significantly declining $(-1.7 \% / y)$. Ruby-throated hummingbird, the only eastern species, is significantly increasing $(1.9 \% / y)$.

Belted kingfisher. Order: Coraciïformes, Family: Alcedinidae, Subfamily: Cerylinae

Belted kingfisher Megaceryle alcyon, although not presently of conservation concern, has been declining significantly at a rate of $-1.6 \% / y$ over the BBS interval. Widespread throughout the eastern, central, and northwestern portions of the BBS survey area, $66 \%$ of this species' range is covered by the BBS. Declines are quite uniform throughout the BBS area; regional analyses indicate that only some portions of the Mississippi Alluvial Valley and Prairie Potholes have nondecreasing populations.

Woodpeckers. Order: Piciformes, Family: Picidae, Subfamily: Picinae (Lewis's woodpecker Melanerpes lewis, red-headed woodpecker Melanerpes enthrocephalus, acorn woodpecker Melanerpes formicizonus, gila woodpecker Melanerpes uropygialis, golden-fronted woodpecker Melanerpes aunifions, red-bellied woodpecker Melanerpes carolinus, Williamson's sapsucker Sphyrapicus thyroideus, yellow-bellied sapsucker, red-naped sapsucker, redbreasted sapsucker, ladder-backed woodpecker Picoides scalaris, Nuttall's woodpecker Picoides nullalliu, downy woodpecker Picoides pubescens, hairy woodpecker Picoides villosus, red-cockaded woodpecker Picoides borealis, whiteheaded woodpecker Picoides albolanatus, American threetoed woodpecker Picoides dorsalis, black-backed woodpecker Picoides arcticus, northern llicker Colaples auratus, gilded flicker Colaptes chrysoides, pileated woodpecker Dryocopus pilealus)

Woodpeckers occupy many regions in North America and vary greatly in their patterns of 
population change. Although three species have $\leq 30 \%$ of their ranges within the BBS area, on average the woodpeckers have $70 \%$ of their ranges in the survey area. Seven of the 21 species are classified as of conservation concern; four of those species (Lewis's woodpecker, red-headed woodpecker, red-cockaded woodpecker, and gilded llicker) are significantly declining, and two (Nuttall's woodpecker and white-headed woodpecker) are significantly increasing. Among the 14 species that are not classified of conservation concern, only goldenfronted woodpecker (a southwestern species) and northern flicker are significantly declining. The remaining species are stable $(N=8)$ or increasing $(\mathcal{N}=4)$.

Pewees, Empidonax flycatchers, and phoebes. Order: Passeriformes, Family: Tyrannidae, Subfamily: Fluvicolinae (olive-sided llycatcher Conlopus cooperi, western wood-pewee Contopus sordidulus, eastern wood-pewee Contopus virens, yellow-bellied llycatcher Empidonax flaviventris, Acadian flycatcher Empidonax virescens, alder flycatcher, willow flycatcher, "Traill's" flycatcher, least flycatcher Empidonax minimus, Hammond's flycatcher Empidonax hammondii, gray flycatcher Empidonax wrighlii, dusky lycatcher Empidonax oberholseri, Pacific-slope and Cordilleran flycatchers [combined], black phoebe Sayornis nigricans, eastern phoebe Sayornis phoebe, Say's phoebe Sayormis saya, vermilion flycatcher Pyrocephalus rubinus)

With few exceptions, most of the flycatchers in this group have large portions of their ranges within the BBS survey area. The three phoebe species are either stable or increasing, but 9 of the 13 other flycatchers and peewee species are declining or have negative but nonsignificant trend estimates. The two species with populations of conservation concern, willow flycatcher $(-1.6 \% / \mathrm{y})$ and olive-sided flycatcher $(-3.5 \% / \mathrm{y})$, are both undergoing significant declines. Vermilion flycatcher has $\sim 10 \%$ of its breeding range in the BBS survey area and shows nonsignificant increases. Declines in aerial insectivores have been documented from BBS data (Nebel et al. 2010), although phocbes tend to breed in human-influenced habitats and hence may show different population trajectories than most other aerial insectivores.

Myiarchus flycalchers and kingtirds. Order: Passenformes, Family: Tyramidae, Subfamily: Tyraminae (ash-throated Alycatcher Myiarchus cinerascens, great crested Ilycatcher Myianchus crinitus, brown-crested flycatcher Myiarchus byannulus, Couch's kingbird Tyrannus couchä, Cassin's kingbird Tyrammus rociferans, western kingbird Tyranmus verticalis, eastern kingbird Tyramus bramus, scissor-tailed Ilycatcher Tyrannus forficatus)

The two grassland-breeding species in this group, scissor-tailed flycatcher and eastern kingbird, are both well-surveyed by the BBS $(\sim 90 \%$ of their breeding ranges in the survey area) and are significantly declining. Four of the other six species are significantly increasing; populations of great crested flycatcher and Cassin's kingbird appear stable. These species vary widely in percentage of range in BBS area, with brown-crested flycatcher and Couch's kingbird having $<10 \%$, Cassin's kingbird having $35 \%$, and all other species having $>70 \%$.

Loggerhead shrike. Order: Passeriformes, Family: Laniidae

Loggerhead shrike Lamius hudovicianus is of conservation concern and is significanly declining $(-3.2 \% / y)$ throughout the $85 \%$ of its breeding range covered by the BBS.

Vireos. Order: Passeriformes, Family: Vireonidae (whiteeyed vireo Vireo griseus, Bell's vireo Vireo bellii, gray vireo Vireo vicinior, yellow-throated vireo Vireo flavifions, plumbeous vireo Vireo plumbeus, Cassin's vireo Vireo cassinï, blue-headed vireo Vireo solitamis, Hutton's vireo Vireo hulloni, warbling vireo Vireo gilvus, Philadelphia vireo Vireo philadelphicus, red-eyed vireo Vireo olivaceus)

On average, $79 \%$ of the ranges of the 11 vireo species are covered by the BBS. Interestingly, only plumbeous vireo is declining $(-2.7 \% / \mathrm{y})$, and most of this species' decline occurred prior to 1980 . Populations of the two species of conservation concern (Bell's vireo and gray vireo) and Philadelphia vireo appear stable. The remaining seven species show significant population increases.

Jays and croves. Order: Passeriformes, Family: Corridae (gray jay Perisoreus canadensis, green jay Cyanocorax yncas, pinyon jay Gymnorhinus cyanocephatus, Steller's jay Cyanocilla stelleri, blue jay Cyanocilla cristala, western scrub-jay Aphelocoma califormica, Clark's nutcracker Nucifraga columbiana, black-billed magpie Pica hudsonia, yellow-billed magpie Pica nuttalli, American crow Corvus brachyrhynch, northwestern crow Corvus caurinus, fish crow Corrus ossifragus, Chihuahuan raven Corrus cryptoleucus, common raven Convus corax)

Fourteen species of corvids are surveyed by the BBS. Among jay and magpie species, four show significant population declines, four appear stable, and only the green jay (which has limited BBS data) shows a significant increase $(8.4 \% / y)$. Black-billed magpie, blue jay, and two species of conservation concern (yellow-billed magpie and pinyon jay) show significant declines. The five species of crows and ravens all have positive or stable trends, and the increases in common raven are significant and noteworthy $(2.5 \% / \mathrm{y})$. Most of these corvids are well-adapted to urban and suburban environments. Exceptions to this pattern include yellow-billed magpie, pinyon jay, gray jay, and Clark's nutcracker, which each prefer forested habitats, and the aridland Chihuahuan raven. American crow shows recent slight population declines that have been associated with exposure to West Nile Virus 
(IaDeau et al. 2007), although populations have now rebounded to pre-exposure levels.

Horned lark. Order: Passeriformes, Family: Alaudidae

A grassland-breeding species of conservation concern, horned lark Eremophila alpesiris has $47 \%$ of its range in the BBS survey area and is significantly declining $(-2.4 \% / y)$.

Martin and swallows. Order: Passeriformes Family: Hirundinidae Subfamily: Hirundininae (Purple martin Progne subis, tree swallow Tachycineta bicolor, violetgreen swallow Tachycinela thalassina, northern roughwinged swallow Stelgidopteryx serripennis, bank swallow Riparia riparia, cliff swallow Petrochelidon pyrrhonota, cave swallow Petrochelidon fulva, barn swallow IHirundo rustica)

These aerial insectivores also tend to be declining. Only two species, the cave swallow of the southwest $(24.8 \% / y)$ and the widespread cliff swallow $(0.4 \% / y)$ show significant and nonsignificant increases, respectively; all other species show declines, and significantly so for purple martin, tree swallow, bank swallow, and barn swallow.

Chickadees and titmice. Order: Passeriformes, Family: Paridae (Carolina chickadee Poecile carolinensis, blackcapped chickadee Poecile atricapillus, mountain chickadec Poecile gambeli, chestnut-backed chickadee Poecile rufescens, boreal chickadee Poecile hudsonicus, oak titmouse Baeolophus inomatus, juniper titmouse Baeolophus ridgwayi, tufted titmouse Baeolophus bicolor)

All of these parids have $>70 \%$ of their breeding ranges in the BBS survey area except for boreal chickadee, which only has $27 \%$ of its range in the area. Two chickadees with ranges in the western United States and Canada (mountain chickadee and chestnut-backed chickadec) are significantly declining, along with oak titmouse, which is also declining and is of conservation concern. Tufted titmouse and black-capped chickadee are significantly increasing.

Verdin. Order: Passeriformes, Family: Remizidae

The verdin Auriparus flariceps, a southwestern species that has only $42 \%$ of its range in the BBS survey area, is significantly declining at a rate of $-2.7 \% / \mathrm{y}$.

Bushtit. Order: Passeriformes, Family: Aegithalidae

Less than half of the breeding range of bushtit Psallipiparus minimus falls into the BBS survey area; BBS results show no significant trend overall.

Nuthatches. Order: Passeriformes, Family: Sillidae, Subfamily: Sillinae (red-breasted nuthatch Silla canadensis, white-breasted nuthatch Sitta carolinensis, pygmy nuthatch Silta pygmaea, brown-headed nuthatch Silta pusilla)

The four species of nuthatches all have $>70 \%$ of their range in the BBS survey area. Brown-headed nuthatch, which breeds in the southeastern United States, is of conservation concern due to declining populations, although the present BBS results have CIs that overlap 0 . BBS data indicate that whitebreasted nuthatch and red-breasted nuthatch are significantly increasing.
Brown creeper. Order: Passeriformes, Family: Certhïdae, Subfamily: Certhiinae

The brown creeper Certhia americana, a widespread forest bird having $71 \%$ of its range covered by the BBS survey area, has positive but nonsignificant trend estimates.

Wrens. Order: Passeriformes, Family: Troglodytidae (cactus wren Campylorhynchus brunneicapillus, rock wren Salpinctes obsoletus, canyon wren Catherpes mexicanus, Carolina wren Thryothorus ludovicianus, Bewick's wren Thryomanes bexickii, house wren Troglodytes aedon, winter wren Troglodytes hiemalis, Pacific wren Troglodytes pacificus, sedge wren Cistothorus platensis, marsh wren Cistothorus palustris)

Of the 10 wren species, three (cactus, Bewick's, and Pacific wren) are significantly declining. Bewick's wren is of conservation concern due to large population losses in eastern parts of its range; its abundance map is based on recent (post-2000) data and illustrates the absence of recent encounters in most eastern states. Carolina wren and winter wren are well-known to be sensitive to prolonged snow cover and so, not surprisingly, show fluctuations relating to severe winters in the eastern United States. Marsh wrens and house wrens significantly increased in population over the BBS time period.

Gnakcatchers. Order: Passeriformes, Family: Sylviidae, Subfamily: Polioptilinae (blue-gray gnatcatcher Polioptila caerulea, black-tailed gnatcatcher Polioptila melanura)

Blue-gray gnatcatcher is increasing $(0.6 \% / \mathrm{y})$ over the $75 \%$ of its range covered by the BBS. The blacktailed gnatcatcher, which has only $34 \%$ of its range surveyed, shows significant declines $(-2.0 \% / \mathrm{y})$ within the surveyed area.

American dipper. Order: Passeriformes, Family: Cinclidae

About half of the range of American dipper Cinclus mexicamus is covered by the BBS, and no trend is evident in the 213 survey routes on which the species is encountered.

Kinglets. Order: Passeriformes, Family: Regulidae (golden-crowned kinglet Regulus satrapa, rubycrowned kinglet Regulus calendula)

Both kinglet species have about half of their breeding ranges in the BBS survey area. Goldencrowned kinglets have significant declines surveywide; ruby-crowned kinglet shows no significant trend.

Wrentit. Order: Passeriformes, Family: Sylviidae

Over 90\% of wrentil Chamaea fasciala range occurs in the BBS survey area, and this species of conservation interest shows significantly $(-0.7 \% / \mathrm{y})$ declining populations.

Bluebirds and thrushes. Order: Passeriformes, Family: Turdidae (eastern bluebird Sialia sialis, western bluebird Sialia mexicana, mountain bluebird Sialia currucoides, Townsend's solitaire Myadestes townsendi, 
veery Catharus fuscescens, Swainson's thrush Catharus ustulatus, hermit thrush Catharus gullalus, wood thrush Hylocichla mustelina, American robin Turdus migratorius, varied thrush Ixoreus naevius)

Turdid thrushes primarily live in forested biomes, although American robins and wood thrush are often associated with human-dominated habitats. On average, $69 \%$ of their ranges are covered by the BBS. Varied thrush $33 \%$ of range surveyed by the BBS) and wood thrush $(100 \%)$ are species of conservation interest, and BBS data indicate that both species are declining in population size. Veery, Swainson's thrush, and mountain bluebird are also significantly declining. Populations of eastern bluebird and American robin are significantly increasing.

Mimic thrushes. Order: Passeriformes, Family: Mimidae (gray catbird Dumetella carolinensis, northern mockingbird Mimus polyglottos, sage thrasher Oreoscoples monlanus, brown thrasher Toxostoma nufum, long-billed thrasher Toxosloma longirostre, Bendire's thrasher Toxostoma bendirei, curve-billed thrasher Toxostoma curvirostre, California thrasher Toxostoma redivizum, crissal thrasher Toxostoma crissale, Le Conte's thrasher Toxostoma lecontel)

Of the 10 mimic thrushes encountered on the BBS, six have significantly declining populations. Only long-billed thrasher, a species for which the BBS covers only $32 \%$ of its range via 38 survey routes in southern Texas, has significantly increasing populations. The three species of conservation interest (Bendire's thrasher, California thrasher, Le Conte's (hrasher) are all significantly declining. The BBS surveys $>80 \%$ of the ranges of seven of the mimic thrushes, but three species (long-billed thrasher, curve-billed thrasher, crissal thrasher) have $\leq 40 \%$ of their breeding range in the BBS survey area.

European starling. Order: Passeriformes, Family: Sumidae

The introduced European starling Sumus vulgaris has $70 \%$ of its breeding range in the BBS survey area and is significantly declining $(-1.4 \% / y)$.

Sprague's pipit. Order: Passeriformes, Family: Molacillidae

Sprague's pipit Anthus spragueii is a grassland species of conservation concern whose range is completely covered by the BBS. The species is significantly decreasing at a rate of $-3.5 \% / \mathrm{y}$.

Cedar waxwing. Order: Passenformes Family. Bombycillidae

Cedar waxwing Bombycilla cedrorum is surveyed over $84 \%$ of its range by the BBS and shows a positive trend that is significant for regression method results but is not for the interval results. A preponderance of states and provinces have increasing populations, and increases are particularly prevalent in the southern portions of the range.

Phainopepla. Order: Passeriformes, Family: Ptilogonatidae

The phainopepla Phainopepla nitens breeds primarily in Mexico, and only $37 \%$ of its range occurs in the BBS survey area. BBS results indicate a stable population.
Longspurs. Order: Passeriformes, Family: Calcarïdae (chestnut-collared longspur Calcanus omatus, McCown's longspur Rhynchophanes mccowini)

Both longspur species have breeding ranges in the northern plains that are completely covered by the BBS, and they are grassland obligate species of conservation concern. Both species are significantly declining, chestnut-collared longspur at $-4.3 \% / \mathrm{y}$ and McCown's longspur at $-5.3 \% / \mathrm{y}$.

Wood warblers. Order: Passeriformes Family: Parulidae (ovenbird Seiurus aurocapillus, worm-eating warbler Helmitheros vermivorus, Louisiana waterthrush Parkesia motacilla, northern waterthrush Parkesia noveboracensis, golden-winged warbler Vermivora chrysoplera, bluewinged warbler Vermivora cyanoptera, black-and-white warbler Mniotilla varia, prothonotary warbler Prolonolaria cilrea, Swainson's warbler Limnolhlypis swainsonii, Tennessee warbler Oreothlypis peregrina, orange-crowned warbler Vermivora celala, Lucy's warbler Oreothlypis luciae, Nashville warbler Vermivora ruficapilla, Virginia's warbler Oreothlypis virginiae, Connecticut warbler Oporomis agilis, MacGillivray's warbler Oporomis Lolmiei, mourning warbler Oporornis philadelphia, Kentucky warbler Oporomis formosus, common yellowthroat Geothlypis trichas, hooded warbler Wilsonia citrina, American redstart Selophaga ruticilla, Cape May warbler Setophaga tigrina, cerulean warbler Selophaga cerulea, northern parula Parula americana, magnolia warbler Setophaga magnolia, baybreasted warbler Selophaga castanea, blackburnian warbler Selophaga fusca, yellow warbler Setophaga petechia, chestnut-sided warbler Setophaga pensylvanica, blackpoll warbler Selophaga striala, black-throated blue warbler Setophaga caenulescens, palm warbler Selophaga palmarum, pine warbler Selophaga pinus, yellow-rumped warbler Setophaga coronata, yellowthroated warbler Setophaga dominica, prairie warbler Selophaga discolor, Grace's warbler Selophaga graciae, black-throated gray warbler Setophaga nigrescens, Townsend's warbler Selophaga lownsendi, hermit warbler Setophaga occidentalis, black-throated green warbler Selophaga virens, Canada warbler Cardellina canadensis, Wilson's warbler Cardellina pusilla, yellowbreasted chat Icteria virens)

Most of the 44 parulid warblers surveyed by the BBS have the bulk of their ranges within the BBS survey area, although blackpoll warbler only has $17 \%$ of its range in the region. Except for the habitat generalist common yellowthroat and the aridlandbreeding Lucy's warbler, all species inhabit forest habitats. Populations of 17 warbler species are significantly declining, and populations of only six species are significantly increasing. Fourteen species are of management concern, including seven with significant declines (prothonotary warbler, goldenwinged warbler, cerulean warbler, Grace's warbler, prairie warbler, Kentucky warbler, Canada warbler). All of these species except Canada warbler (which is 
also found in other forest biomes) have their entire ranges in eastern forest habitats and within the BBS survey area. Nonsignificant negative trends occur in four species of conservation concern (bay-breasted warbler, blue-winged warbler, Virginia's warbler, and hermit warbler), and populations of the other species of conservation concern appear to be stable (Lucy's warbler, Swainson's warbler, and wormeating warbler).

New World sparrowes. Order: Passeriformes, Family: Emberizidae (olive sparrow Arremonops rufivirgalus, green-tailed towhee Pipilo chlorums, spotted towhee Pipilo maculalus, eastern towhee Pipilo erythrophlhalmus, rufous-crowned sparrow Aimophila nuficeps, canyon towhee Melozone fusca, California towhee Melozone crissalis, Abert's towhee Pipilo aberti, Cassin's sparrow Peucaea cassinii, Bachman's sparrow Peucaea aestivalis, chipping sparrow Spizella passerina, clay-colored sparrow Spizella pallida, Brewer's sparrow Spizella breweri, field sparrow Spizella pusilla, black-chinned sparrow Spizella alrogularis, vesper sparrow Pooeceles gramineus, lark sparrow Chondestes grammacus, blackthroated sparrow Amphispiza bilineala, sage sparrow Amphispiza belli, lark bunting Calamospiza melanoconys, savannah sparrow Passerculus sandwichensis, grasshopper sparrow Ammodramus sazannamu, Baird's sparrow Ammodramus bairdii, Henslow's sparrow Ammodramus henslowiil, Le Conte's sparrow Ammodramus leconteï, Nelson's sparrow Ammodramus nelsoni, seaside sparrow Ammodramus manitimus, fox sparrow Passerella iliaca, song sparrow Melospiza melodia, Lincoln's sparrow Melospiza lincolnü, swamp sparrow Melospiza georgiana, whitethroated sparrow Zonotrichia albicollis, white-crowned sparrow Zonotrichia leucophnys, dark-eyed junco funco hyemalis)

The New World sparrows include many scrubsuccessional, aridland, and grassland breeding species known to be declining. The only species showing a significant increase $(3.1 \% / y)$ is olive sparrow, for which the BBS covers only $6 \%$ of its range. Of the 34 species in the group, 17 have significant declines, but 27 have negative estimates of trend. The geographic and temporal extent of declines in the group has stimulated a discussion of the role of habitats in conservation (U.S. NABCI Committee 2009). The BBS provides the primary source of population information for 13 of the group's conservation concern species. Of these, five have significantly declining populations. Two species of conservation concern have noteworthy patterns of population change. Henslow's sparrow has had increasing populations in recent years, and its nonsignificant decline reflects these recent increases. Baird's sparrow experienced significant declines $(-3.0 \% / y)$, but populations appear to have experienced more stability in recent years.

Tanagers, cardinals, grosbeaks, and buntings. Order: Passeriformes, Family: Cardinalidae (hepatic tanager
Piranga flaza, summer tanager Piranga nubra, scarlet tanager Piranga olivacea, western tanager Piranga ludoviciana, northern cardinal Cardinalis cardinatis, pyrrhuloxia Cardinalis simuatus, rose-breasted grosbeak Phencticus ludoricianus, black-headed grosbeak Phencticus melanocephalus, blue grosbeak Passerina caerulea, lazuli bunting Passerina amoena, indigo bunting Passerina cyanea, painted bunting Passerina ciris, dickcissel Spiza americana)

Most species in this group breed in forested habitats, albeit often in gaps or successional areas. Exceptions include the grassland-breeding dickcissel, which is a species of conservation concern that the BBS indicates to be declining. Similarly, the aridland-breeding pyrrhuloxia is also declining (regression results). The eastern-breeding rose-breasted grosbeak shows population declines, while the western black-headed grosbeak is increasing. Indigo bunting is significantly declining while painted bunting (a species of conservation concern) and lazuli bunting show negative but nonsignificant trends. Amongst the tanagers, western tanager and summer tanager are significantly increasing; Scarlet tanager shows insignificant trends. Northern cardinal, which is often associated with human communities, is significantly increasing.

New World blackbirds. Order: Passeriformes, Family: Icteridae (bobolink Dolichonyx oryzivonus, red-winged blackbird Agelamus phoeniceus, tricolored blackbird Agelaums tricolor, eastern meadowlark Surnella magna, western meadowlark Shumella neglecla, yellow-headed blackbird Xanthocephahus xanthocephahus, rusty blackbird Euphagus carolinus, Brewer's blackbird Euphagus cyanocephalus, common grackle Quiscalus quiscula, boat-tailed grackle Quiscalus major, great-tailed grackle Ouiscalus mexicanus, bronzed cowbird Molothus aeneus, brown-headed cowbird Molothrus ater, orchard oriole Icterus spurius, hooded oriole Icterus cucullatus, Bullock's oriole Icterus bullockï, Baltimore oriole Ictenus galbula, Scott's oriole Icterus parisorum)

BBS results indicate that most blackbirds are declining; only 1 of the 18 species (great-tailed grackle) is significantly increasing but 11 species are significantly declining. The limited BBS data for rusty blackbird (only $27 \%$ of the breeding range is in the BBS survey area) corroborate declines documented from Christmas Bird Counts (Niven et al. 2004). Grassland-breeding species such as meadowlarks and bobolink have well-documented declines (Peterjohn and Sauer 1999). Orioles with northern distributions show significant declines; southwestern species (hooded and Scott's orioles) do not show significant population changes. Tricolored blackbird, which is a species of conservation concern, shows positive but nonsignificant population changes. The large but highly variable counts of tricolored blackbird make estimation of site effects very imprecise, and these large variances are reflected in the inflated indexes for this species. Other 
blackbirds and grackles (except for great-tailed grackle) are declining. Brown-headed cowbird is declining, and the $10 \%$ of the bronzed cowbird's range covered by the BBS shows no trend for that species.

Finches, crossbills, and grosbeaks. Order: Passeriformes, Family: Fringillidae, Subfamily: Carduelinae (pine grosbeak Pinicola enucleator, purple finch Carpodacus purpureus, Cassin's finch Carpodacus cassinii, house finch Carpodacus mexicanus, red crossbill Loxia curvirostra, white-winged crossbill Loxia leucoplera, pine siskin Carduelis pinus, lesser goldfinch Carduelis psaltria, Iawrence's goldfinch Carduelis lawrencei, American goldfinch Spimus tristis, evening grosbeak Coccolhrausles vesperlinus)

Most of these species show significant declines. Lawrence's goldfinch is the only species of conservation concern in this group, and BBS results suggest a nonsignificant decline for its population. Purple finch and Cassin's finch are significantly declining, and house finch, although it had dramatically increased subsequent to its introduction in New York during the $1940 \mathrm{~s}$, has recently experienced declines related to a pathogenic mycoplasma bacterium (Hochachka and Dhondt 2000). Pine grosbeak, evening grosbeak, and the two crossbills have very imprecise results from the BBS, although both grosbeak species show significant declines.

Weaver finches. Order: Passeriformes, Family: Passeridae (house sparrow Passer domesticus, Eurasian tree sparrow Passer montanus)

Both these species were introduced to North America. BBS indicates significant declines in the very widespread house sparrow but significant increases in the very local Eurasian tree sparrow.

\section{Summary of "State of the Birds" and other species group results}

Summary information for the species groups are presented in Appendix B.

Aridland birds. The 61 species of aridland birds summarized in BBS analyses inhabit desert and Great Basin regions in the western and southwestern United States. The 17 obligate species show a composite total decline of $39.7 \%$ over the interval 1968-2011. The Bayesian estimate of percentage of species with negative trend estimates is $88 \%(95 \%$ CI: 71, 100).

Grassland birds. Grassland birds, both the 41 total species and the 24 obligates monitored by the BBS, have been showing consistent declines throughout the BBS interval. Obligate species have declined in composite $37.8 \%$ between 1968 and 2011 ; 75\% <63, 83) of the obligate species had negative trend estimates.

Boreal forest birds. These 80 species and 24 obligate species live primarily in six northern BCRs, and much of their ranges are north of the BBS survey area. For the obligate species, on average $42 \%$ of their breeding ranges are in the BBS survey area. Overall, obligate boreal forest birds show a nonsignificant $7.5 \%$ decline over the interval. Fiftyfour percent $(42,71)$ of the species have negative trend estimates.

Eastern forest birds. The 111 eastern forest species form a very heterogeneous group occurring in 10 BCRs. However, the 25 obligate species have significantly declined over the interval by $24 \%$. These declines reflect the presence of early successional species, along with several declining neotropical migrant species. The Bayesian estimate of percentage of species with negative trend estimates is $68 \%\langle 60,76\rangle$.

Subtropical forest birds. This small collection of 15 species that occur in Texas and Florida contains several widespread species with rapidly increasing populations. Almost all populations in this group are increasing, possibly due to northward expansion of ranges from regions south of the BBS survey area. The Bayesian estimate of percentage of species with negative trend estimates is $13 \%(6,20)$.

Western forest birds. There are 114 species of western forest birds, and 37 obligate species. The species show no consistent population changes over the 1968-2011 period.

Wetland birds. These 103 species rely on wetlands in some way, and form a heterogeneous group. The composite long-term change for the collection of species is a nonsignificant $21.4 \%$. The Bayesian estimate of percentage of species with negative trend estimates is $48 \%(40,54)$.

Marsh birds. These 29 species are obligate to wetlands with emergent vegetation. Many of them are poorly surveyed by the BBS, and the composite long-term change for the collection of species is a nonsignificant $-1.5 \%$. The Bayesian estimate of percentage of species with negative trend estimates is $55 \%(34,72)$.

Generalists. These 65 species occur in more than three primary habitats but have a wide variety of lifehistories, hence the group has little meaning aside from the notion of broad habitat usage. In composite, they have been increasing between 1968 and 2011 by an imprecisely estimated but significant $32.2 \%$. The Bayesian estimate of percentage of species with negative trend estimates is $49 \%(43,55)$.

Urban/suburban birds. The 117 species in this group are able to coexist with human populations. Within this heterogeneous group, populations have been increasing (a composite estimate of change of $18.3 \%$ ), but that estimate is imprecise and its credible interval overlaps 0 . The Bayesian estimate of percentage of species with negative trend estimates is $46 \%(50,56)$.

Exotic birds. These eight species were introduced into North America, and several species are now 
among the most abundant bird species on the continent. This group shows a composite nonsignificant increase of $15 \%$ during the survey interval, with the large variation in the composite change reflecting heterogeneity in change among the species in the group. Four of the species have undergone significant declines over the interval, and only Eurasian tree sparrow is significantly increasing. The Bayesian estimate of percentage of species with negative trend estimates is $63 \%$ (50, 75).

Neotropical migrant birds. The 133 species of neotropical migrant birds show a decline of $-10.5 \%$ over the 19682011 interval, although the $95 \%$ CI overlaps 0 . The Bayesian estimate of percentage of species with negative trend estimates is $60 \%(55,65)$.

Temperate migrant birds. The 181 species of temperate migrant birds show a nonsignificant change of $-4.1 \%$ over the 1968-2011 interval. The Bayesian estimate of percentage of species with negative trend estimates is $56 \%(51,60)$.

Permanent resident birds. The 95 species of permanent resident birds show a composite nonsignificant increase of $12.1 \%$ over the 1968-2011 interval. The Bayesian estimate of percentage of species with negative trend estimates is $49 \%$ (44, 56).

\section{Discussion}

\section{Population change in North American birds}

The BBS covers most of North America and provides data for a diverse collection of bird species. Users of the data have long been challenged by the need to present summary results from the BBS in a way that adequately conveys the uncertainty associated with the temporal and geographic scope of the survey. In this report, we have attempted to present information about population change with an appropriate context for interpreting the results, allowing readers to evaluate the relevance of the long-term trend estimate in the context of temporal and spatial variation in the species' population. Simple summaries of these data are inevitably misleading; metrics of change must be carefully defined to provide appropriate context.

Interval-specific estimates of change provide a starting point for interpretation of survey results. Our analysis shows that $57 \%$ of the 426 North American bird species we analyzed experienced significant changes over the 19662011 interval, with $36 \%$ of species experiencing significant declines and $21 \%$ of species significantly increasing over the interval. These very general summaries, although often cited and used to motivate conservation activities, do not adequately reflect the complexity of population change. Although interpretation of the metric often assumes that the number represents both consistent change within the interval and a prediction of future change, for many species this assumption is not true. For example, trends computed over the interval 2001-2011 are often not consistent with the 1966-2011 trends; only 14\% of species showed significant declines $27 \%$ showed significant increases) in the most recent decade. Examination of population change estimates by state or province, or by BCR within species, documents further complexity in population change inherent within bird species. Of course, there are species for which change does appear consistent over space and time. Most species, however, are not consistently declining or increasing among regions, and we encourage readers to examine the species accounts to have a better context for evaluating change.

Grouping species by common characteristics such as migration status (e.g., neotropical migrant birds; Robbins et al. 1989) or habitat affinities (e.g., grassland breeding birds; Peterjohn and Sauer 1999) has proven to be a powerful means of synthesis of BBS results. Grassland- and aridlandbreeding birds are well-known to be declining, primary based on BBS analyses (U.S. NABCI Committee 2009). Indications of declines in neotropical migrant birds (Robbins et al. 1989) were an important motivating force for establishment of Partners in Flight (Rich et al. 2004). As with individual species data, temporal patterns occur in composite trends for the species groups, and our group summaries allow readers to examine the temporal patterns in the composite index to better interpret these group summary results. One issue that remains to be explored is spatial variation in group summaries, and we have developed (but not yet implemented) methods for regional group summaries that accommodate regional differences in species pools.

Neotropical migrant bird results provide a case study for the need to consider all of these issues in group summary analyses. Robbins et al. (1989) documented temporal patterns in population change of neotropical migrant birds in the eastern part of the continent (Robbins et al. 1989). This widely cited paper motivated a great deal of public concern for migrants. However, Sauer and Droege (1992) documented regional variation in declines of neotropical migrant birds; western species were generally increasing in population while eastern species were declining. The decades of additional data since those initial results indicate that declines in population have not continued even in the eastern United States. These inconsistencies in time and space of population change in neotropical migrant birds highlight the need for caution in interpretation of BBS results. 


\section{Use of BBS data to evaluate why bird populations are changing}

Documenting patterns of population change from BBS data generally does not provide insights into why populations are changing. Historically, documenting patterns of population change was viewed as sufficient information for managers. Identification of consistent declines among groups of species has been an important component of bird conservation, in which monitoring data has been used to identify declining species, after which conservation focuses on searching for causes of declines by identifying species- or group-specific factors influencing the population. This "declining population paradigm" (Caughley 1994) has been used to focus conservation efforts on grassland and aridland birds, and declines documented from BBS data provided a strong rationale for conservation efforts for those species. This paradigm is still prevalent in bird conservation, as shown by the conservation interest in aerial insectivore species after declines were documented in BBS data (e.g., Nebel et al. 2010).

However, the BBS is used in a large variety of scientific studies of factors influencing population change in birds. Nichols et al. (2012) notes that observation of patterns in survey results leads to weak inference, but that development of a priori hypotheses about factors influencing population change and testing them using survey data lead to stronger inference. BBS data are frequently used in this way (e.g., LaDeau et al. 2007), and it is often convenient to formulate these alternative hypotheses in terms of covariates that may correlate with population change. Using this approach, the BBS has proven effective in providing quantitative assessments of the effects of environmental stressors on birds. Climate change is likely to increase the frequency of severe storms and other weather events, and analysis of BBS data has allowed us to begin the study of these effects on regional population change (Butler 2000). Severe winters influence bird populations, and using BBS data we now directly model change in bird populations as a function of winter severity (Sauer et al. 1996; Iink and Sauer 2007). For resident and short-distance migrant species such as Carolina wren and eastern bluebird, severe winters had long been known to have negative effects on their local populations; BBS data allow us to quantify these effects at a regional scale and to evaluate differential effects on species (Iink and Sauer 2007).

Hierarchical models described in this monograph can be easily modified to accommodate covariates, and we can use alternative models to more fully integrate BBS analyses into the process of understanding why bird populations are changing via two approaches: 1) by using direct covariate analyses to assess the importance of possible environmental stressors; and 2) by using alternative models directly in adaptive management, in which monitoring is paired with management to both assess the consequences of management and improve our models of why bird populations change.

\section{Issues in the analysis of BBS data}

In the species accounts, we focus on presentation of quantitative results and identification of possible concerns associated with the analysis. Sauer et al. (2003) defined deficiencies in the analysis of change associated with 1) limited data, due to either very small sample sizes or limited survey information from the species' range; 2) low counts of some species on BBS routes; 3) imprecise results, indicating poor ability to evaluate population change; and 4) inconsistency in estimates of change over time (e.g., www.mbr-pwrc.usgs.gov/bbs/cred.html). Sauer et al. (2003) summarized the frequency of these deficiencies for several groups of species. In the species accounts, we indicate when limited data and imprecise results occur in the hierarchical model analysis.

Species and range coverage. Over 900 species of birds have been observed in North America north of Mexico (Birdwatching.com 1998). Over 500 of these species are encountered on BBS survey routes. Of these, we summarized population change for 426 species. The remaining species are generally represented by small numbers of observations and have ranges largely outside the BBS-surveyed area. Even among species for which we conduct trend analysis, the percentage of the species' range that is monitored can vary from virtually 0 (e.g., great blackbacked gull) to 100 (e.g., sage grouse). On average, the surveyed area covers $66 \%$ of ranges of species for which we estimate population change using BBS data. This percentage varies among the indicator groups, with grassland-obligate species having an average of $86 \%$ of their ranges in the surveyed area but borealforest obligate species having an average of $43 \%$. Incomplete coverage of species' ranges has consequences for the interpretation of the survey because no information exists on how population change in the surveyed area relates to the population change of the entire population.

Concerns about incomplete range coverage are sometimes mitigated by focusing on regional estimates of change. Most jurisdictions (e.g., states) have an interest in population status within their boundaries, and the BBS can provide estimates of population change for many regions. However, without an understanding of change at the scale of species' ranges, it is diflicult to assess the importance of changes at local and regional scales. For example, one of the challenges of BBS analysis is keeping track of species whose ranges are expanding into the surveyed area. Tropical species such as crested caracara that historically bred in limited numbers in 
the surveyed area have been expanding northward. This component of BBS analysis is often neglected in discussions of the quality of survey data, but as the potential for climate change to affect bird populations increases, population change in peripheral portions of species' ranges may play increasingly larger roles in the dynamics of the species. The documentation of portion of current ranges surveyed by the BBS presented here is an important lirst step in defining these areas, and provides a context for interpreting species' trends. The BBS survey area and bird ranges will likely change in the future, and understanding the dynamics of both will be critical for appropriate interpretation of BBS data.

Precision of estimates. One issue of particular relevance for interpreting results from the hierarchical model analysis is precision. The hierarchical model analyses clearly show the lack of precision in estimates of trend and annual indexes for many species. In particular, many regions had limited samples in the early years of the survey; hence indexes from those earlier years have large credible intervals. This was not evident in earlier analysis, and the estimating equations analysis, which does not control for limited data in early years, ofien provided misleading views of change for species with limited data in early (or later) years (Link and Sauer 2002; Sauer and I ink 2011). Imprecise estimates have always been an issue for the BBS; hierarchical model analyses provide users with appropriate information regarding precision of indexes and trends over time.

Sauer and Link (2011) used half-widths of 95\% CIs to assess the precision of interval trend estimates from BBS data. Using results from 1966 to 2009, and following the cut points for precision described by Sauer et al. (2003), they found that 68 species $(16 \%)$ had $95 \%$ CIs that would not detect a $3 \% / y$ population change, and 25 species $(6 \%)$ had $95 \%$ CIs that would not detect a $5 \% / y$ population change. Thus, the majority of long-term trend estimates meet minimum standards for precision (Sauer et al. 2003). As noted in Sauer et al. (2003), any such standard for precision is arbitrary unless explicitly tied to a predicted change associated with a management objective or to some other significant population objective. However, these values are useful as measures of precision consistent with earlier analyses.

One of the advantages of hierarchical models used in our analysis is that the precision of annual indexes can be readily calculated using MCMC. Earlier analyses, generally presented without credible intervals, often conveyed a false impression of reliability. Providing credible intervals clearly shows some systematic patterns of imprecision related to the history and logistical constraints of the survey. The most obvious of these patterns is that population time series for many species show extremely imprecise annual indexes for the first years of the survey. This is a consequence of the limited data available in the early years of the survey; the BBS did not begin in the central United States until 1967 and in the western United States until 1968, and coverage in terms of number of routes surveyed has increased steadily throughout the survey period (Sauer and Link 2010). For many species, precision of annual indexes has increased over time as shown by decreases in width of CIs. However, population changes for a variety of species are consistently estimated imprecisely from BBS data. Species such as eared grebe have indexes with large credible intervals for all years. The CIs form an important additional source of information for BBS analyses and make users of BBS data much more aware of the limited value of results for some imprecisely estimated species (Sauer and Link 2011). We agree with their observations; indexes presented without CIs in earlier analyses led users to overestimate the quality of the results.

Relative abundance. It is well known that counts of birds along BBS routes are underestimates of the actual numbers of birds present and that these indexes are influenced by a variety of environmental factors, which complicate any use of BBS data as estimates of population size (Thogmartin et al. 2006). Simplistic summaries of the data such as route regression relied on scaling of annual indexes for presentation so that midyear of the indexes was an average of mean counts on survey routes. For many species, this had the desirable effect of presenting indexes at a level associated with the mean counts. However, for species with extreme or imprecise estimates of change, this scaling resulted in unrealistically large abundances in extreme years. The hierarchical model offers an improved scaling of indexes, as species-abundance is defined in the context of the model, and these model-based estimates control for route and observer effects in the summary. However, because the model is $\log$ linear, the results need to be transformed to a linear scale, and this transformation requires addition of variance components $\left(0.5 \sigma_{\omega}^{2}+0.5 \sigma_{\varepsilon}^{2}\right)$ when computing indexes $n_{i, t}$. For most species, $n_{i, t}$ is similar to the historical weighted mean counts used to scale annual indexes, but for a few species the addition of these variance components leads to annual indexes that are larger than the mean counts (Sauer and Link 2011). The issue of scaling annual indexes and the concerns among users when modelbased estimates of abundance scale differently from simple averages of route counts reflect the complexity that arises when sophisticated models are applied to the diversity of datasets produced by the BBS. It is well known that simple estimates of abundance are biased, but users often develop intuition for results based on observation of the simple estimates. Modelbased estimates of abundance occasionally produce 
results that conflict with this intuition, and these challenges to intuition are useful because they cause us to consider both the validity of the model structure and the deficiencies of simple summaries. In the case of the abundance indexes, values that exceed the naive estimates of abundance indicate that the model is producing large variances among sites, suggesting that users should be cautious in any inference based on the abundances.

The BBS and endangered species. Endangered species have strict legal requirements for monitoring, and BBS data are often requested to inform both the consideration of species for threatened or endangered status and to provide information on status for species presently endangered. However, the BBS was specifically designed as a monitoring program for widespread and relatively abundant species, and the design is not well suited for rare or difficult-to-detect species. Consequently, the BBS can contribute to status assessments for relatively widespread species such as cerulean warbler and mountain plover, but of the species of North American birds known to be endangered, threatened, or declining, many have very restricted distributions, habitats, or life history traits that make the BBS a poor survey for them. Of the 74 listed species (U.S. NABCI Committee 2009), the BBS provides no results for 71 and imprecise results for three species: wood stork, least tern, and redcockaded woodpecker. The BBS also provides information for several species that contain listed subspecies, although in general no useful data exist for the listed subspecies.

\section{Addressing concerns about the credibility of the BBS as a source of information regarding bird population change}

Presenting analysis results from the BBS requires confidence in the credibility of the results. We view our analyses as controlling for known sources of bias in estimation, and thus providing reasonable estimates of population change. As with all surveys, we feel that the BBS methods and analyses should always be open to modification due to results of ongoing research and statistical developments that could provide less-biased and/or more precise estimates. For the BBS, this scrutiny is particularly important because the design of the BBS has been a target of criticism from the start of the program (D. R. Anderson, USGS, personal communication.). Aside from issues of coverage and precision described earlier, concerns about inherent flaws in the survey methods still exist. These issues have been the topic of extensive research but are still controversial among users and analysts of BBS data. The BBS Strategic Plan (U.S. Geological Survey 2007) sets explicit research goals to evaluate and address these concerns. Two primary criticisms of the BBS relate to roadside sampling issues and pointcount limitations, and in the following sections we brielly describe these issues and ongoing efforts to mitigate the concerns.

Roadside sampling concerns. Bird populations along roadsides differ from nonroadside locations in abundance, and habitats may be changing at different rates along roadsides than in adjacent offroad habitat, raising the concern that estimates of both population size and population change based on roadside surveys may not be representative of the nonroadside population. This concern was raised during review of initial designs for the BBS, but at the time the logistical advantages of a purely roadside design outweighed needs for additional sampling of roadside habitats. Roadside-survey issues have been an ongoing topic of discussion among survey coordinators because roadsides have direct as well as indirect influences on counting (Griffith et al. 2010). Low counts of marsh and wetland birds have historically been thought to provide evidence of underrepresentation of their primary habitats along roadsides, and a variety of on- versus off-road studies have found varying results regarding differences in bird abundance, depending on species and habitats considered (e.g., Hutto et al. 1995; Keller and Fuller 1995). We conducted onand off-road BBS-style counts in Delaware, Maryland, Pennsylvania, Virginia, and West Virginia in June 2000 to evaluate the feasibility of conducting off-road surveys. We found that differences occurred between on- and off-road estimate of total abundance of warblers and sparrows (estimated collectively). On- and off-road differences also occurred in individual species results. For example, for red-eyed vireos total abundance was 74.0 (95\% Confidence interval 50.6397 .37$)$ on 50 roadside counts, $126.3(96.00-156.59)$ on 50 offroad counts.

Often, differences between on- and off-road abundances and trends are inferred from differences in amounts of habitats and rates of change in habitats. Interpreted aerial photographs have been used to assess roadside and off-road habitat differences and relative rates of change in habitats over time, with indications that forested habitats may be underrepresented and urban habitats tend to be more frequent along roadsides (Bart et al. 1995; Keller and Scallan 1999). Interpreted Landsat information can be used to evaluate amounts of habitat along and away from roadsides at a regional scale. Veech et al. (2012) found that habitats along BBS routes were representative of regional habitats at the scale of BCRs, but that at local scales lightly developed open space habitats were overrepresented. Hannan (2009) used the Land Cover Trends Study (Loveland et al. 2002) to evaluate whether 
consistent differential changes occurred in habitats on- vs. ofl-roads between 1973 and 2000. He found little overall differential change in habitats, although consistent differences did exist in rates of change between subperiods within the larger interval (Hannan 2009).

Detection probability concerns. Point counts are well known to provide biased estimates of population size, leading Link and Sauer (1998:261) to make the observation that "BBS sampling cannot guarantee either a census or a known fixed area of sampling." The general strategy for analysis of BBS data has been to add covariates and structure to the analysis to model and control for factors known to influence detection of birds along survey routes. The primary factor known to influence detectability and influence trend is variation among and within observers, and the hierarchical model presently used for BBS analysis controls for both observer differences and start-up effects. Ongoing research is directed at identifying and modeling other features that influence detection of birds and may be influencing our estimation of population change. Recent analyses have evaluated the need for additional controls for traflic disturbance (Griflith et al. 2010) and for changes in phenology effects by incorporating year day as a covariate in the analysis. Changes in road noise due to traflic effects have likely not influenced our estimates of population change (Griflith et al. 2010). Changes in phenology have significantly affected the estimates of trend for only three species, and for those species the differences were in magnitude, not in direction (J. R. Sauer, unpublished data).

Field methods associated with procedures such as multiple observer counts (Nichols et al. 2000; Riddle et al. 2010) or distance sampling (Rivera-Milan et al. 2003) are candidate modifications of the traditional point count to permit direct estimation of detection rates in BBS analyses. In the past, concerns about additional time, analytical needs, and burdens on the volunteer observers associated with these methods have precluded their implementation in BBS sampling. However, a larger suite of methods is now available than could have been employed when the BBS was started, computer advances have revolutionized data management, and modern analytical methods can incorporate these approaches by adding additional components to the hierarchical model described above (e.g., Kéry et al. 2009). Although it is not yet clear whether any of the approaches presently under consideration will yield a viable BBS protocol to replace the standard point count, the recent BBS review has motivated field trials of several approaches to detectability estimation to advance our understanding of the methods (e.g., Riddle et al. 2010; D. Twedt, USGS Patuxent Wildlife Research Center, unpublished data). Final- ly, alternative analytical approaches that provide model-based estimates of detection probability may provide some opportunities for direct estimation of detection in the context of estimation of population change (Dail and Madsen 2011).

\section{Statistical analysis methods}

Hierarchical models are a natural approach for the analysis of BBS data. BBS data are multiscale, and these models provide sufficient flexibility to permit inference at scales from individual points to continental. Implementation of the models in Bayesian analyses provides for the first time a framework in which the deficiencies of the survey design can be accommodated during the analysis. The framework allows for many alternative parameterizations of the model and allows us to extend the modeling to consider covariates that influence both abundance and trend, tying the analysis more closely both to scientific study of factors influencing bird populations and to models that can directly be used to predict the consequences of management activities. This linkage to management through habitat and other covariates in critical to enhancing the relevance of the $\mathrm{BBS}$ as a component of management.

Any generic approach to the analysis of many species in a complicated dataset is prone to limitations. For some species, there are insuflicient data to allow inference for at least some strata, and this lack of information contributes to poor convergence and very imprecise estimates. We screened the results and eliminated these regions from summary analyses of states and BCRs in the species accounts; identification and accommodation of these regions in the analysis, by elimination or through aggregation with adjacent regions, is a necessary component of any BBS analysis.

Another complication relates to the subtle interplay between the structure of the model and our ability to estimate model components. The model we used has a trend estimated in the context of random-eflect year effects. Alternative parameterizations of year effects could include year effects as random effects without a trend, year effects as fixed effects, or year effects as change from prior years (Pannekock and van Strien 2005). Although similar quantities are estimated with these parameterizations, in practice the results can be quite different when they are applied to the same dataset. Because the BBS has been unevenly implemented over time, some regions have no data or very limited data in the early years of the survey. Year effect parameterizations can vary greatly in how they accommodate this limited data; simple random effects or fixed effect models can be extremely imprecise or can shrink the estimated year effect to some temporally invarying mean. 
In our view, some association with time should be included with year effects in the model. The parameterization presented here was originally implemented to accommodate fitting in sparse datasets since the trend component provides a structure even when no data may exist for a particular year (Sauer and Geissler 1990). Autoregressive models (e.g., modeling first differences in year effects; Iink and Barker 2010:29l) provide an alternative approach to incorporating time in the year effects model. Our experience with implementing an autoregressive model indicates that trend estimates generally are similar to those presented here, but estimated trends tend to be less extreme (i.e., closer to 0). Analyses of BBS data with alternative models enhances our understanding of this complicated dataset, and we hope to expand the "toolkit" for analyses of these data with both additional models for analysis and model selection procedures for better defining which model is best for a data set.

\section{Conclusion: BBS analysis and technological advances}

During a workshop presentation at the 2006 International Ornithological Congress in Veracruz, Mexico, Chandler Robbins presented his perspective on the history and future prospects of the BBS (Robbins 2006). One intriguing aspect of his talk was a description of the effects of advances in technology on the conduct and management of the BBS. In 1966, communication with observers was via letter, copies were made with mimeograph machines, and data were entered into computers via keypunch machines. Computing resources were very limited, permitting only simple analyses, and logistical necessity placed limits on routes that could be surveyed and data that could be entered. Robbins made the point that the capabilities available in 2006 were unimaginable in 1966, and that we must continue to innovate using the technology of the present.

Although the innovations he mentioned are most obvious in terms of communication and passing information to and from observers, present capabilities for field methods, analysis, and communication of results are also vastly different. The hierarchical model used to estimate population change can be conveniently fit using the computer-intensive MCMC approaches, and these remarkable methods are allowing for the first time implementation of Bayesian analysis in realistic experimental situations. This important advance is expressed throughout this monograph, as estimation of population change for individual species, ranking of change for states, provinces, and BCRs, and composite summaries of population change for species groups are all based on Bayesian inference that could not have been conducted using the computational resources of 1966 (or even in 1986, when JRS conducted his first BBS analyses). In our view, these methods have for the first time allowed us to conduct analyses of BBS data that accommodate the constraints imposed by the need to accommodate differences among the thousands of observers who have counted birds for four decades over most of a continent. Another critical aspect of these analyses is their flexibility, with new innovations such as detectability estimation or additional covariates being able to be directly incorporated as components within the hierarchical model.

The last comprehensive summary of the BBS was published in 1986 (Robbins et al. 1986). Since that time, web applications have made all the data and analyses readily available to all users through the BBS Summary and Analysis Website (Sauer et al. 2011). Results and summaries presented here provide a synthesis of those data in a format readily readable on a variety of digital displays. This monograph is explicilly designed to be an electronic document, which we view as the only feasible means to present results from an annual survey. We intend to use the summary analyses and formats presented in this document to inform (and be updated by) future versions of the BBS Summary and Analysis Website

\section{Acknowledgments}

As scientists who use the information from the survey, we acknowledge our debts to Dr. Chandler S. Robbins (Frontispiece), who had the vision and energy to develop the survey and remains its greatest advocate, to the coordinators who have augmented the program and maintained the information, and to the thousands of volunteers who conduct the surveys and dutifully submit the information to be analyzed and presented to the world. C. S. Robbins, S. Droege, B. Peterjohn, and W. Thogmartin reviewed versions of this document, and C. Handel's careful review and editing greatly improved the manuscript. J. Aycrigg provided the State of the Birds habitats map used in the species group summaries.

Any use of trade, product, or firm names is for descriptive purposes only and does not imply endorsement by the U.S. Government.

\section{Literature Cited}

Bart J, Hofschen M, Peterjohn BG. 1995. Reliability of the brecding bird survey: effects of restricting surveys to roads. The Auk 112:758-761.

Birdwatching.com, 1998, The 914 wild bird species of North America. Available: www.birdwatching.com/software/birdlists/ north_amer98.html (May 2013).

Butcher GS, Niven DK, Panjabi AO, Pashley DN, Rosenberg KV. 2007. Watcht ist: The 2007 WatchL ist for United States Birds. American Birds 61:18-25.

Butler RW. 2000. Stormy seas for some north american songbirds: are declines related to severe storms during migration? The Auk 117:518-522.

Carson RS. 1962. Silent Spring. Boston: Houghton Mifflin. 
Caughley G. 1994. Directions in conservation biology. Journal of Animal Licology 63:215 244.

Chesser RT, Banks RC, Barker IK. Cicero C, Dunn JL, Kratter AW, Iovette IJ, Rasmussen PC, Remsen Jr. JV, Rising JD, Stotz. DF, Winker K. 2011. Fifty-second supplement to the American Ornithologists' Union check-I ist of North American bircds. Auk 128:600 613.

Dail D. Madsen L. 2010. Models for estimating abundance from repeated counts of an open metapopulation. Biometrics 67:577-587.

Drocge S, Saucr JR. 1990. Northern bobwhite, Gray partridge, and ring-necked pheasant population trends (1966-1988) from the North Amcrican Brceding Bird Survcy. Pages 2-20 in Church KE, Warner RE, Brady SJ, editors. Perdix V: Gray Partridge and Ring-Necked Pheasant Workshop. Limporia: Kansas Department of Wildlife and Parks.

Environmental Systems Rescarch Institute, 1991. Surface modeling with TIN. Redlands, California: Environmental Systems Rescarch Institutc, Inc.

liather CH, Sauer JR. 1996. Using landscape ecology to test hypotheses about large-scale abundance pattems in migratory songbirds. Lcology 77:28-35.

Geissler PH, Noon BR. 1981. Lstimates of avian population trends for the North Amcrican Brecding Bird Survey. Pages 42-51 in Ralph CJ, Scott JM, cditors. Estimating numbers of terrestrial birds. Studies in Avian Biology 6. Tawrence, Kansas: Cooper Ornithological Society.

Geissler PH, Sauer JR. 1990. Lopics in route regression analysis. Pages 54-57 in Saucr JR, Drocge S, cditors. Survey designs and statistical methods for the estimation of avian population trends. U.S. Fish and Wildlife Scrvice, Biological Report 90(1).

Gregory RD, van Strien AJ, Vorisek P, Gmelig Meyling AW, Noble DG, lioppen RPB, Gibbons DW. 2005. Developing indicators for Luropean birds. Philosophical Iransactions of the Royal Society 360:269 288.

Griffith EH, Saucr JR, Royle JA. 2010. Traffic effects on bird counts on North American Brecding Bird Survey routes. The Auk 127:387-393.

Hannan MD. 2009. Land cover change and the Breeding Bird Survey: rates of change in relation to roads. Master's thesis. Brookings: South Dakota State University.

Hochachka WM, Dhondt AA. 2000. Density-dependent decline of host abundance resulting from a ncw infectious discasc Proceedings of the National Academy of Sciences of the United States of America 97:303-530.

Hutto RL, Hejl SJ, Kelly Jl; Pletschet SM. 1995. A comparison of bird detection rates derived from on-road versus off-road point counts in Northern Montana. Pages 103-110 in USDA Forest Service General Technical Report PSW-GTR-149.

Isaaks LH, Srivastava RM. 1989. An introduction to applied geostatistics. New York: Oxford University Press.

Keller CM, Fuller MR. 1995. Comparison of birds detected from roadside and off road point counts in the Shenandoah National Park. Pages 111-116 in USDA Forest Scrvice General Tcchnical Report PWS-GTR-149.

Keller CML, Scallan J'I'. 1999. Potential roadside biases due to habitat changes along Breeding Bird Survey routes. Condor 101(1): :50-57

Kendall WT. Peterjohn BG, Saucr JR. 1996. First-time observer effects in the North American Brecding Bird Survey, Auk 113: 823-829.

Kéry M, Dorazio RM, Soldaat L, van Strien A, Zuiderwijk A, Royle JA. 2009. Trend estimation in populations with imperfect detection. Journal of Applied Lcology 46:1163-1172.

I.aDeau SI, Kilpatrick A.M, Marra PP. 2007. West Nile virus cmergence and large-scale declines of North Amcrican bird populations. Nature 2059:1-4.

Link WA, Barker RJ. 2010. Bayesian inference with ecological applications. New York: Academic Press.

I.ink WA, Saucr JR. 1994. Fstimating cquations estimates of trends. Bird Populations 2:23-32

I ink WA, Saucr JR. 1998. Modcling and cstimation of population from the North American Breeding Bird Survey. Lcological Applications 8:258-268.

Link WA, Sauer JR. 2002. A hierarchical model of population change with application to Gerulcan Warblers. Ecology 83: $2832-2840$.
Iink WA, Saucr JR, 2007. Scasonal components of avian population change: joint analysis of two large-scale monitoring programs. Lcology 88:49-55.

Loveland TR, Sohl TI, Stchman SV, Gallant AI, Sayler KI, Napton DE. 2002. A strategy for estimating the rates of recent United States land-cover changes. Photogrammetric Fnginecring \& Remote Sensing 68:1091-1099.

Lum DJ, Thomas A, Best N, Spiegelhalter D. 2000. WinBUGS a Baycsian modelling framcwork: concepts, structurc, and cxtcnsibility. Statistics and Computing 10:325-337.

Martin IW, Pospahala RS, Nichols JD. 1979. Assessment and population management of North American migratory birds. Pages 187-239 in Cairns J Jr, Patil GP, Waters WL, editors. Environmental biomonitoring, assessment, prediction, and managcment - certain case studics and related quantitative issues. Statistical ecology. Vol. 11. lairland, Maryland: International Cooperative Pub House.

Nebel S, Mills A, McCracken JD, Taylor PD. 2010. Declines of acrial insectivores in North America follow a gcographic gradicnt. Avian Conscrvation and Fcology-Écologic ct conservation des oiseaux 5(2): 1. Available: http://www.ace-eco. org/vol5/iss2/artl/ (May 2013)

Nichols JD, Gooch EG, Nichols JM, Saucr JR. 2012. Studying biodiversity: is a new paradigm really necded? PioScience 62: $497-502$.

Nichols JD, Hines JE, Sauer JR, liallon I; l'allon J, Heglund PJ 2000. A double-observer approach for estimating detection probability and abundance from avian point counts. The Auk 117:393-408.

Niven DK, Sauer JR, Butcher GW, I ink WA. 2004. Population change in boreal birds from the Christmas Bird Count. American Bird 58:10 20.

Pannckock J, van Stricn A. 2005. TRIM 3 Manual (TRends \& Indices for Monitoring data). Statistics Nctherlands Project No. 100384, 171-01-1MO, 17 le lebruary 2005.

Peterjohn BG, Sauer JR. 1999. Population status of North American grassland birds from the North American Breeding Bird Survey, 1966-1996. Studics in Avian Biology 9:27-44.

Rich TD, Bcardmore CJ, Berlanga H, Blancher PJ, Bradstrect MSW, Butcher GS, Demarest DW, Dunn LH, Hunter WC, Iñigo-Llias LE, Kennedy.JA, Martell AM, Panjabi AO, Pashley DN, Rosenberg KV, Rustay C.M, Wendt JS, Will TC. 2004 Partners in Flight North American Iandbird Conservation Plan. Ithaca, New York: Cornell Lab of Ornithology, Partners in light.

Riddle JD, Pollock KH, Simons TR. 2010. An unreconciled double-observer method for estimating detection probability and abundance. The Auk 127:841-849.

Ridgely RS, Allnutt 11. Brooks T, McNicol DK. Mehlman DW, Young BL, Look JR. 2007. Digital distribution maps of the birds of the Western Hemisphere, version 3.0. Arlington, Virginia: NaturcServe

Rivera-Milan FF, Ruiz. CR, Cruz JA, Mazquez. M, Martincz AJ 2003. Population monitoring of plain pigeons in Puerto Rico. Wilson Bulletin 115:45-51.

Robbins CS. 2006. Fstablishing the BBS north of Mexico: Icssons lcarned. Presentation in Workshop on Mexican Expansion of the North American Breeding Bird Survey (BBS). Berlanga H, Downes C, Pardieck K, Ziolkowski D, organizers. 3 October 2006, Veracruz, Mexico.

Robbins CS, Bystrak D, Geissler PH. 1986. The Brecding Bird Survey: its first fiftecn ycars, 1965-1979. U.S. Fish and Wildlife Service, Resource Publication 157.

Robbins CS, Sauer JR, Greenberg RS, Droege S. 1989. Population declines in North American birds that migrate to the ncotropics. Proccedings of the National Acadcmy of Sciences of the United States of America 86:7658-7662.

Root 'I'. 1988. Atlas of wintering North American birds. University of Chicago Press.

Sauer JR, Droege S. 1990. Recent population trends of the castern blucbird. Wilson Bulletin 102:239-252.

Saucr JR, Drocge S. 1992. Gcographic patterns of population trends of Neotropical migrants in North America. Pages 2642 in Hagan JM III, Johnson DW, editors, Lcology and conservation of neotropical migrant landbirds. Washington, D.C.: Smithsonian. 
Sauer JR, lallon JL, Johnson R. 2003. Use of North American Breeding Bird Survey data to estimate population change for bird conservation regions. Journal of Wildlife Management 67: 372-389.

Sauer JR, Gcissler PH. 1990. Annual indices from route regression analyses. Pages 5862 in Sauer JR, Droege S, editors. Survey designs and statistical methods for the estimation of avian population trends. U.S. Fish and Wildlife Service, Biological Report 90(1).

Sauer JR, Hines JL, liallon J. 2008a. The North American Breeding Bird Survey, results and analysis 1966-2007. Version 5.15.2008. Laurel, Maryland: USGS Patuxent Wildlife Rescarch Center. Available: www.mbr-pwrc.usgs.gov/bbs/ bbs2007.html (May 2013).

Sauer JR, Hines JL, lallon JL, Pardieck KL, Ziolkowski DJ Jr, Link WA. 2011. The North American Breeding Bird Survey, Results and Analysis 1966-2010. Version 12.07.2011. Taurcl, Maryland: USGS Patuxent Wildlife Research Center. Available: http://www.mbr-pwrc.usgs.gov/bbs/bbs.html (May 2013).

Sauer JR, I ink WA. 2002. Hicrarchical modeling of population stability and specics group attributes using Markov Chain Montc Carlo methods. Ecology 83:1743-1751.

Sauer JR, Link WA. 2011. Analysis of the North American Breeding Bird Survey using hierarchical models. Auk 128:87 98.

Sauer JR, Link WA, Kendall WT, Kelley JR, Niven DK. 2008b. A hicrarchical model for cstimating change in American woodcock populations. Journal of Wildlife Management 72 : $204-214$.

Sauer JR, Pendleton GW, Orsillo S. 1995. Mapping of bird distributions from point count surveys. Pages 151-160 in Ralph C.J. Sauer JR, Droege S, editors. Monitoring bird populations by point counts. USDA liorest Service, Pacilic Southwest Rescarch Station, Gencral Technical Report PSW GTR 149.

Saucr JR, Pendleton GW, Petcrjohn BG. 1996. Evaluating causes of population change in North American insectivorous songbirds. Conservation Biology 10:465 478.

Sauer JR, Peterjohn BG, I ink WA. 1994. Observer differences in the North American Brceding Bird Survey. Auk 111:50-62.

ter Braak GJF, Van Strien AJ, Meijer R, Verstracl TJ. 1994. Analysis of monitoring data with many missing values: which method? Pages 663673 in Hagemeijer LjM, Verstrael IJ, cditors. Bird Numbers 1992. Distribution, monitoring and ccological aspects. Proccedings of the 12th International Conference of IBCC and $\mathrm{EOAC}$, Noordwijkerhout, The Netherlands. Voorburg: Statistics Netherlands; Beek-Ubbergen: Heerlen \& SOVON.

Thogmartin WE, Howe FP, James FC, Johnson DH, Recd E, Saucr JR, Thompson FR III. 2006. A revicw of the population estimation approach of the North American Landbird Conservation Plan. Auk 123:892 904.

Thogmartin WE, Saucr JR, Knutson MG. 2004. A hicrarchical spatial model of avian abundance with application to Cerulcan Warblers. Lcological Applications 14:1766-1779.

Thomas L. 1996. Monitoring long-term population change: why are there so many analysis methods? Lcology 77:49-58.

Thomas I, Burnham KP, Buckland ST. 2004. Temporal inferences from distance sampling survcys. Pages 71-107 in Buckland ST, Anderson DR, Burnham KP, Laake JL, Borchers DL, Thomas L, editors. Advanced distance sampling. Oxford, United Kingdom: Oxford University Press.

U.S. Department of the Intcrior. 2011. Endangered and threatened wildlife and plants; withdrawal of the proposed rule to list the Mountain Plover as threatened. lederal Register 76(92): 27756 27799

U.S. Fish and Wildlife Scrvice. 2008. Birds of conservation concern 2008. Arlington, Virginia: United States Department of Interior, lish and Wildlife Service, Division of Migratory Bird Management.

U.S. Gcological Survey. 2007. Stratcgic plan for the North Amcrican Brceding Bird Survcy: 2006-2010. U.S. Gcological Survey Circular 1307.

U.S. North American Bird Conservation Initiative Committee. 2009. State of the Birds, United States of Amcrica, 2009. Washington, D.C.: U.S. Department of Interior.
Vecch JA, Small MF, Baccus JT, 2012. Representativeness of land cover composition along routes of the North American Breeding Bird Survey. The Auk 129:259 267.

\section{Appendix A}

\section{Species accounts}

Found at DOI: 10.3996/nafa.79.0001.A1.

In this appendix, species accounts are presented for 426 North American bird species and two combined species. Each species account contains (1) general information; (2) a population change summary table; (3) a mean relative abundance map; (4) a survey-wide annual index graph; (5) a population change map; (6) a state and Provincial population change summary graphic; and (7) a BCR population change summary graphic.

1. General Information presents taxonomic information about the species, along with information on habitats, migration status, and conservation status as described in the 2009 State of the Birds Report (U.S. NABCI Committee 2009).

- The major habitats in which the species occurs are listed, categorized as Marsh, Grasslands, Aridlands, or Forests (Boreal, Western, Eastern, or Subtropical). Species occurring in $>3$ major habitats are categorized as Generalists.

- Species that occur primarily in one major habitat are further categorized as Habitat Obligates.

- Secondary habitats are specialized sub-habitats, such as Wetland, Urban/Suburban, and Coastal areas, which may occur across all major habitats.

- Exotic (nonnative) species are not categorized by habitat.

- Species are considered to be of conservation concern if they are designated as Watchlist species by the National Audubon Society and American Bird Conservancy (Butcher et al (2007), listed as Birds of Conservation Concern (BCC) by the U.S. Fish and Wildlife Service (2008), or listed as threatened or endangered under the U.S. Endangered Species Act.

- Migration status is categorized as Permanent Resident, Temperate Migrant, or Neotropical Migrant. Lists of migration status were developed by the State of the Birds Science Team (unpublished data).

- We also present percentage of the species' Western-hemispheric range occurring in the BBS survey area. 


\section{The Population Change Summary table} presents trend data (yearly \% change) for the long-term (1966-2011) and most recent 10 years (2001-2011), along with 95\% credible intervals (CI). The interval-based estimates directly estimate change in annual indices based on the ratio of the first and last index for the interval. An alternative estimate of trend, based on a linear regression through the survey-wide annual indices for the long-term period, is also presented. Results from the 2 approaches are largely consistent; we present regression results for users who prefer the alternative approach. If the CI for the interval-based estimate does not contain 0.0 , we judge the trend estimate to be significant. We use colors to indicate cautions associated with results. Green text represents a need for caution in interpretation of results (e.g., due to low abundances or small samples); Red text suggests that a serious deficiency exists in the results. The level of concern is defined as a consequence of small sample sizes or imprecise estimates:

- Sample sizes are defined in terms of number of random BBS routes on which the species was encountered survey-wide. A small number of nonrandom routes exist in the survey database but were not used in the analysis. Small sample sizes $(<50)$ are flagged for caution. Very small samples $(<14)$ are flagged as possibly unreliable.

- We classified estimated trends as imprecise if their CIs are sufficiently wide that a change of $3 \% / \mathrm{yr}$ change would include 0 . We defined extremely imprecise trends as those whose CIs are sufficiently wide that a change of $5 \% / \mathrm{yr}$ change would include 0 .

3. Mean Relative Abundance Maps are based on BBS data for the interval 2007-2011. Data were averaged by route then abundances were computed for specific locations defined by a grid covering the survey area using an area-weighted averaging of route data. Note that the stippled area in the northern part of the continent represents areas with very limited samples that were excluded from our analysis. BBS data from Alaska and Mexico were also excluded.

4. Graph of Survey-wide Annual Indexes shows annual indexes of abundance estimated using the hierarchical model. Medians of the posterior distribution of the yearly indexes are shown as solid lines with year markers; lower $(2.5 \%)$ and upper $(97.5 \%)$ CIs are shown as solid lines.

5. Population Change Maps for the BBS survey area were produced using data from 19662011. Estimates of local annual population change were

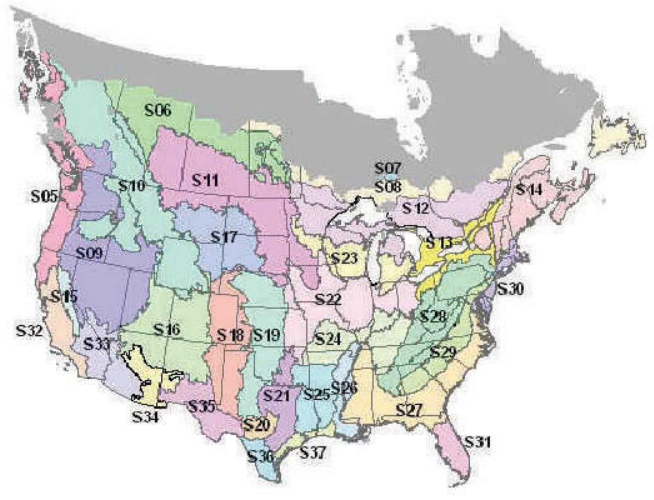

Figure A. Map of Bird Conservation Regions referenced in Appendices A and B. BCR names corresponding to codes presented in the map are: S01 Aleutian/Bering Sea Islands, S02 Western Alaska, S03 Arctic Plains and Mountains, S04 Northwestern Interior Forest, S05 Northern Pacific Rainforest, S06 Boreal Taiga Plains, S07 Taiga Shield and Hudson Plains, S08 Boreal Softwood Shield, S09 Great Basin, S10 Northern Rockies, S11 Prairie Potholes, S12 Boreal Hardwood Transition, S13 Lower Great Lakes/St. Lawrence Plain, S14 Atlantic Northern Forest, S15 Sierra Nevada, S16 Southern Rockies/ Colorado Plateau, S17 Badlands and Prairies, S18 Shortgrass Prairie, S19 Central Mixed-grass Prairie, S20 Edwards Plateau, S21 Oaks and Prairies, S22 Eastern Tallgrass Prairie, S23 Prairie Hardwood Transition, S24 Central Hardwoods, S25 West Gulf Coastal Plain/Ouachitas, S26 Mississippi Alluvial Valley, S27 Southeastern Coastal Plain, S28 Appalachian Mountains, S29 Piedmont, S30 New England/Mid-Atlantic Coast, S31 Peninsular Florida, S32 Coastal California, S33 Sonoran and Mojave Deserts, S34 Sierra Madre Occidental, S35 Chihuahuan Desert, S36 Tamaulipan Brushlands, and S37 Gulf Coastal Prairie.

calculated for the grid of locations using a routeregression analysis of the 15 nearest routes.

6. Graph of Population Change by State or Province provides trend estimates from 19662011 for each state and province in which the species occurs. Note that the ranking is based on a hierarchical model that accommodates differences in precision (Sauer and Link 2002), but the estimated trends are shown on the graphic. In the ranking, imprecise trends tend to be "shrunk" toward the mean trend, and consequently the ordering of trends is shuffled to show the actual ordering (based on the predictions from the model) rather than the naive ordering. The hierarchical model was also used to directly estimate the percentage of state and provinces with decreasing populations. This summary thus displays the estimated state and provincial trends which are our best estimate of the data for the region, but also portrays our best information regarding atributes of the collection of species. The ranks and the number of decreasing species are best analyzed 
using the hierarchical model in which inference is based on the underlying parameters.

7. Graph of Population Change by Bird Conservation Region (BCR) provides trend estimates for BCRs (e.g., Sauer et al. 2003) in which the species occurs (Figure A). These results are also presented as a precision-adjusted ranking using the hierarchical model presented by Sauer and Link (2002).

\section{Appendix B}

\section{Species group summaries}

Found at DOI: 10.3996/nafa.79.0001.A2.

Composite summaries of population change for 19 species groups of North American birds are presented using data from the BBS. Summaries are provided for indicator groups described in the State of the Birds Report (U.S. NABCI Committee 2009, http://www.stateofthebirds.org/) and for species grouped by migratory status.

\section{General Information includes}

- Primary Bird Conservation Regions that encompass the geographic regions associated with each group;

- Total number of species in the group (see hup:// www.stateofihebirds.org for lists of species);

- Percentage of the species in the group for which the BBS provides regional summaries. The BBS does not cover all species of any group, and this percentage shows how comprehensive the BBS coverage is for the group;

- Average percentage of species' ranges in the BBS survey area.
2. The Locale Map for Group shows the portions of the United States and southern Canada that contain habitats suitable for species in the group. Data for the contiguous U.S. were summarized from a map of primary habitats prepared by the National Gap Analysis program in conjunction with the 2010 State of the Bird Report (http://www.stateofthebirds. org); participants in the analysis categorized habitats as characteristic of the species groups. For portions of the survey that occur in Canada, we stipple the BCR areas most likely to contain the group. For groups such as generalist species or migration types in which localities cannot be specified, the entire BBS survey area is indicated.

3. The Population Change Summary table presents the number of species in the BBS analysis, and the total percentage composite change over 42 years with associated $95 \%$ credible interval (CI).

4. The graph of Composite Change for Species Group displays the composite total change from the base year (1968) for the collection of species, along with its 95\% CI.

5. The Long-term Population Trends graph shows the estimated trend from 1966-2011 from the species in the group, along with their 95\% CIs. Trends are ranked from largest estimated decline to largest increase. This species-by-species summary of change shows the range of change among species in the group, and the precision of the changes. Species with imprecise trend estimates (large CIs) contribute little to the overall summaries.

6. The table of Long-term Annual Population Change lists species in the group, with their estimated trends (1966 2011), associated 95\% CIs, and sample sizes ( $\mathrm{N}$ of routes). 